\title{
Assessing the veracity of Precambrian 'sponge' fossils using in situ nanoscale analytical techniques
}

A. D. Muscente*, F. Marc Michel, James Dale, and Shuhai Xiao

Department of Geosciences, Virginia Polytechnic Institute and State University, Blacksburg, VA 24061, USA

*Corresponding author. Tel.: +1 540200 5634; fax +1 5402313386

Email address: adm97@vt.edu (A. D. Muscente)

\begin{abstract}
Paleontological inferences, molecular clocks, and biomarker fossils indicate sponges evolved in the Cryogenian, but Precambrian sponge fossils are rare, poorly substantiated, and controversial. Spicule-like microstructures (SLMs) hosted in phosphatized fossils from the Ediacaran Doushantuo Formation ( 635-551 Ma) at Weng'an of South China have been interpreted as cylindrical siliceous monaxons, and their hosting fossils as the oldest demosponges in the fossil record. In order to assess their veracity as the oldest spiculate demosponges, we utilize a suite of in situ nanoscale analytical techniques—including scanning electron microscopy, synchrotron Xray fluorescence mapping, X-ray absorption near edge structure (XANES) spectroscopy, focused ion beam electron microscopy, and transmission electron microscopy—to evaluate the ultrastructures and elemental, chemical, and mineralogical compositions of the SLMs. Our data decisively shows that the SLMs are carbonaceous in composition and rectangular in transverse sections, and therefore, are not cylindrical siliceous spicules. Instead, the SLMs may be microbial strands, axial filaments of early hexactinellids, or acicular crystals molded by organic
\end{abstract}


matter. Regardless, our new data invalidate the oldest and only Precambrian demosponges with mineralized spicules. These results indicate that interpretations of Precambrian sponge fossils should be scrutinized with compositional, mineralogical, and ultrastructural data collected using in situ analytical techniques. In addition, our conclusions affirm that no unequivocal biomineralizing sponges occur below the Ediacaran-Cambrian boundary. If hexactinellids and demosponges did diverge in the Cryogenian as suggested by molecular clocks and biomarkers, they either evolved biomineralization long after their divergence or their biomineralized spicules were never preserved until after the Ediacaran-Cambrian boundary. In either case, the dearth of biomineralizing sponge fossils in the Precambrian and their abundance in the early Cambrian must reflect a geobiologically-significant aspect of the Precambrian-Phanerozoic transition.

Keywords: Biomineralization, Doushantuo Formation, Ediacaran Period, Spicules, Sponges

\section{Introduction}

Sponge fossils are common in the Cambrian (Antcliffe et al., 2014; Steiner et al., 1993; Xiao et al., 2005), but conspicuously rare in the Precambrian. The Ediacaran appearances of metazoan reefs (Penny et al., 2014), eumetazoan-grade skeletons (Hua et al., 2005), and bilaterian trace fossils (Chen et al., 2013; Gehling et al., 2014) indicate that sponges, cnidarians, and bilaterians diverged in the Ediacaran Period or earlier. Additionally, molecular clock analyses date the divergence of silica-biomineralizing hexactinellid and demosponge classes at >750 Ma (Erwin et al., 2011; Sperling et al., 2010), and suggest that spiculate demosponge subclades diverged in the Cryogenian or the earliest Ediacaran Period (Sperling et al., 2010). Furthermore, demosponge-specific biomarkers date the origin of demosponges at $>635 \mathrm{Ma}$ 
(Antcliffe, 2013; Love et al., 2009). However, the Precambrian fossil record includes only dubious and equivocal aspiculate sponges (Maloof et al., 2010; Sperling et al., 2011; Wallace et al., 2014; Wang and Wang, 2011), spiculate sponges (Clites et al., 2012; Du et al. 2014; Gehling and Rigby, 1996; Li et al., 1998b; Serezhnikova and Ivantsov, 2007), and sponge spicules (Allison and Awramik, 1989; Brasier et al., 1997; Du and Wang, 2012; Steiner et al., 1993). Although these controversial fossils could potentially fill the gap between the divergence of sponges in the Cryogenian and the first unequivocal sponge fossils in the early Cambrian, their interpretation as sponge fossils has been questioned (Antcliffe et al., 2014; Yin et al., 2001; Zhou et al., 1998).

Spiculate sponges and sponge spicules have the best potential to be preserved and recognized in the fossil record. In contrast to aspiculate sponge fossils, which problematically resemble other soft-bodied fossils such as macroalgae and microbial mats, spiculate sponges and sponge spicules possess diagnostic mineralogical and morphological characters. They also constitute the majority of Phanerozoic sponge fossils, and are expected to be preserved in the Precambrian, if biomineralizing sponges did evolve prior to the Ediacaran-Cambrian boundary as suggested by the molecular clocks (Erwin et al., 2011; Sperling et al., 2010). Yet, Precambrian spiculate sponges and sponge spicules are rare, poorly-substantiated, and controversial. Thus far, none of the spiculate sponges described from the Precambrian have been authenticated on morphological and mineralogical grounds (Antcliffe et al., 2014). Consequently, they could alternatively be macroalgae or microbial mats (Antcliffe et al., 2014) or non-biomineralizing animals (Serezhnikova, 2007). Spicule-like structures disseminated in Precambrian rocks are also problematic (Brasier et al., 1997; Du and Wang, 2012; Steiner et al., 1993). If they are sponge spicules, they should be cylindrical structures with the axial canals, axial symmetries, and 
sometimes concentric growth layers that distinguish spicules from abiogenic acicular crystals and organic microfossils (Allison and Awramik, 1989; Antcliffe et al., 2014; Steiner et al., 1993; Yin et al., 2001; Zhou et al., 1998). However, reports of Precambrian spicule-like structures generally contain insufficient data regarding such morphological and mineralogical characters to verify sponge affinities.

In situ analytical techniques allowing for nanoscale characterization of fossils can be used to critically assess of the veracity of putative Precambrian sponge fossils. The basic utility of these techniques was recently demonstrated by Antcliffe et al. (2014), who used energydispersive X-ray spectroscopy (EDS) to show that spicule-like structures preserved within chert concretions from the Ediacaran Tsagaan Gol Formation ( $\sim 545 \mathrm{Ma}$ ) of southwestern Mongoliaoriginally interpreted as siliceous hexactinellid spicules (Brasier et al., 1997)—contain higher concentrations of arsenic, iron, and sulfur than surrounding chert, and therefore, are probably cruciform arsenopyrite crystals, as hypothesized by other authors (Zhou et al., 1998). In addition to such fundamental compositional information, analytical techniques can also be used to collect in situ data regarding mineralogy (Wacey et al., 2014) and ultrastructure (Schiffbauer and Xiao, 2009), thereby providing a multitude of observations for testing phylogenetic interpretations.

Despite the potential of such techniques to generate substantive information pertinent to paleobiological controversies, they have not been widely employed in studies of Precambrian ‘sponge’ fossils.

In this paper, we demonstrate the utility of in situ analytical techniques for studying the compositions, mineralogies, and ultrastructures of putative Precambrian sponge fossils by characterizing spicule-like microstructures (SLMs, $<5 \mu \mathrm{m}$ in diameter, $10-100 \mu \mathrm{m}$ in length) occurring within phosphatized fossils from the Ediacaran Doushantuo Formation at Weng'an, 
South China (Li et al., 1998b). These phosphatized fossils were originally interpreted as the oldest demosponges in the fossil record (Li et al., 1998b), and are purportedly the only Precambrian sponges preserved with mineralized spicules. The SLMs were interpreted as siliceous monaxons on the basis of their supposed acicular shape, purported siliceous composition, and proximity to putative sclerocytes within the phosphatized fossils (Li et al., 1998b). However, the inferred siliceous composition of the SLMs was based on the observation that SLMs survived $4 \mathrm{M}$ hydrochloric acid treatment, not spectroscopic or diffraction data (Li et al., 1998b), and although apparent axial canals have been illustrated in two SLMs (Li et al., 1998a), such diagnostic features have not been observed in other studies (Yin et al., 2001; Zhang et al., 1998). For these reasons, the hypotheses that the phosphatized fossils are demosponges and the SLMs are siliceous spicules have been cursorily questioned (Antcliffe et al., 2014; Yin et al., 2001; Zhang et al., 1998), though never thoroughly tested. Zhang et al. (1998) argued against a spicule interpretation—likening the SLMs to acritarch spines—but did not actually analyze the SLMs. Similarly, Yin et al. (2001) hypothesized that the SLMs are diagenetic crystals, similar to co-occurring fascicular and dumbbell-shaped crystals. However, because the micrometric SLMs are embedded in nanocrystalline apatite, the low-resolution and low-sensitivity analytical techniques used by Yin et al. (2001) were unable to determine the composition and the transverse sectional morphology of the SLMs; their EDS analysis of SLMs was likely contaminated by surrounding phosphatic material.

Until now, no in situ compositional, mineralogical, or ultrastructural data existed to assess the various interpretations of SLMs in the phosphatized fossils at Weng'an. Using light and scanning electron microscopy (SEM), we screened over 100 petrographic thin-sections to locate SLMs for EDS, synchrotron X-ray fluorescence (XRF) elemental mapping, and X-ray 
absorption near edge structure (XANES) compositional analyses. To study their ultrastructure, we prepared in situ transverse sections through SLMs using dual-beam focused ion beam electron microscopy (FIB-EM). A SLM transverse section was also prepared as an ultra-thin ( 100 nm thick) foil for mineralogical studies using bright field (BF) transmission electron microscopy (TEM), BF scanning transmission electron microscopy (BF-S/TEM), and selected area electron diffraction (SAED). Data from these analyses show that the SLMs are neither cylindrical nor siliceous, and therefore, the demosponge monaxon interpretation is invalidated. We provide several alternative interpretations for testing in future investigations, and conclude our report by reviewing the Precambrian record of sponge fossils in the context of our results and by discussing causes for the dearth of biomineralizing sponge fossils prior to the EdiacaranCambrian boundary.

\section{Geological Setting}

The fossils in this study were collected from the upper Doushantuo Formation at a phosphorite mine ( $\mathrm{N} 27^{\circ} 00.948$ ', E $107^{\circ} 23.221$ '; elevation: $1200 \mathrm{~m}$ ) near Weng’an in Guizhou Province, South China. In the Weng'an area, the Doushantuo Formation is divided into 5 units (Fig. 1; Muscente et al., 2015; Xiao et al., 2014a; Xiao et al., 2014b). Unit 1 ( 5-10 m thick)—a cap dolostone-overlies the Cryogenian Nantuo diamictite. Above it, unit 2-the lower phosphorite ( 8-15 m thick) —is a thin-bedded, peloidal phosphorite with interbedded dolostone and siltstone. It is overlain by unit $3(\sim 2-4 \mathrm{~m}$ thick), a massive dolostone topped by a prominent karstification surface (Xiao and Knoll, 2000; Xiao et al., 1998). Unit 4-the upper phosphorite bed ( 3-10 m thick)—is an intraclastic phosphorite consisting of an organic-rich "black" phosphorite facies (unit 4A, 0.5-5 m thick) overlain by dolomitic "gray" phosphorite facies 
(unit 4B, 1-5 m thick) (Dornbos et al., 2006). This unit contains various three-dimensionally preserved fossils (Xiao et al., 2014a), including filamentous structures (Xiao and Knoll, 1999), multicellular algae (Xiao et al., 2004), acritarchs (Xiao et al., 2014b), putative metazoan embryos (Chen et al., 2014; Xiao et al., 1998), and the purported demosponges containing SLMs (Li et al., 1998b). All these fossils are cellularly replicated by nanometer-sized fluorapatite crystals (Cunningham et al., 2012; Schiffbauer et al., 2012; Xiao and Knoll, 1999). Unit 4 is overlain by unit 5 ( 10 m thick), a phosphatic dolostone that may contain a karstification surface (Jiang et al., 2011; Zhu et al., 2007). It is overlain by the thick dolostone of the Dengying Formation.

The maximum age of the Doushantuo is constrained by a zircon U-Pb age of $636.4 \pm 4.9$ Ma from the Cryogenian Nantuo Formation (Zhang et al., 2008). Published radiometric ages from the Doushantuo Formation at Weng’an include $\mathrm{Pb}-\mathrm{Pb}$ isochron ages of 599 $\pm 4 \mathrm{Ma}$ (Barfod et al., 2002) and 576 $\pm 26 \mathrm{Ma}$ (Chen et al., 2004) from unit 4. Condon et al. (2005) argue that phosphorite diagenesis may have compromised the reliability of the $\mathrm{Pb}-\mathrm{Pb}$ dates. Instead, they propose that the karstification surface atop unit 3 may be a glacioeustatic response to the 582584 Ma Gaskiers glaciation (Hoffman and Li, 2009), implying that the fossils in this study are younger than $584 \mathrm{Ma}$. Alternatively, the karstification surface in unit 5 at Weng'an may be related to the Gaskiers glaciation—an interpretation that does not contradict the $599 \pm 4$ Ma age from unit 4. If so, the fossils in this study from unit 4 are 580-600 Ma (Xiao et al., 2014b).

\section{Material and methods}

Samples were collected from units 4A and 4B. Billets of samples were cut, polished, and mounted to petrographic glass slides to make $\sim 30 \mu \mathrm{m}$ thick petrographic thin-sections. About one hundred thin-sections were examined via transmitted-light microscopy, and transmitted-light 
images were collected. High resolution composite transmitted-light images of phosphatized fossils and SLMs (indicated in figure captions) were assembled from multiple higher magnification images taken at the same focal lengths and using the same exposure settings. Forty thin sections with phosphatized fossils containing SLMs were imaged and elementally mapped using a low vacuum Hitachi' ${ }^{\mathrm{TM}}$ TM3000 Tabletop thermionic (tungsten filament electron source) SEM with backscattered electron (BSE) solid state detector (SSD) and Bruker ${ }^{\mathrm{TM}}$ Xflash compact EDS detector. Thin-sections were not coated prior to SEM and EDS analyses. BSE images and EDS elemental maps were acquired at $15 \mathrm{keV}$ accelerating voltage and $12 \mathrm{~mm}$ working distance. EDS elemental mapping scan live times were $400-500$ s with $~ 8000$ counts/s. Given the operating conditions, the tungsten filament electron source, and the count rate, the dead time should be within an acceptable range ( $10-40 \%$ live time) for elemental mapping analysis. SEM-based EDS data were processed using the Quantax 70 Microanalysis Software by Bruker $^{\mathrm{TM}}$, designed for the Hitachi TM3000 SEM.

Two thin-sections_each containing two SLMs (or SLM fascicles) located approximately $3 \mu \mathrm{m}$ below the polished thin section surfaces—-were subsequently coated with $10 \mathrm{~nm}$ thick AuPd in preparation for FIB-EM. All FIB-EM analyses were conducted using a FEI ${ }^{\mathrm{TM}}$ DualBeam Helios 600 NanoLab equipped with a field-emission gun electron source, Everhart-Thornley detector (ETD) of secondary electrons (SEs) and BSEs, a S/TEM detector, and a focused $\mathrm{Ga}^{+}$ion beam column for controlled, nanoscale material addition and excavation (Schiffbauer and Xiao, 2009). SE images of the SLMs (or SLM fascicles) were acquired throughout FIB preparation using the ETD (configured with a positively-biased Faraday cage) at $5 \mathrm{keV}$ accelerating voltage (Muscente and Xiao, accepted). Milling of the thin section was conducted using the $\mathrm{Ga}^{+}$ion beam at $30 \mathrm{kV}$ accelerating voltage. The working distance was adjusted periodically. Thin ( 1 
$\mu \mathrm{m}$ thick) layers of Pt were deposited on the surfaces of the thin-sections above the SLMs (or SLM fascicle) prior to milling using the $\mathrm{Ga}^{+}$FIB. The SLM fascicle transverse section prepared as an ultra-thin foil using FIB-EM was removed from the slide using a micromanipulator probe, secured to a copper TEM grid, and ion polished to 100 nm thickness. BF-TEM, BF-S/TEM, and SAED analyses of the ultra-thin foil were conducted at $200 \mathrm{keV}$ using a JEOL TM 2100 TEM with thermionic source and high-resolution EDS detector. TEM and BF-S/TEM images were processed using JEOL ${ }^{\mathrm{TM}}$ Analysis Program software. TEM-based EDS elemental maps were acquired at $200 \mathrm{keV}$ with a scan time of 26 minutes (dwell time, 2 ms; resolution, 1024x768 pixels), and were processed using JEOL ${ }^{\mathrm{TM}}$ AnalysisStation software package.

Phosphatized fossils were also extracted from unit 4B samples using the standard acetic acid maceration technique (Xiao and Knoll, 2000). Samples were macerated in 10-15\% acetic acid for 3-6 days, after which, the maceration residuals were washed, drained, and dried. The fossils were then picked individually from the maceration residue, mounted on copper tape, and coated with 20 nm thick C for electron imaging using a FEI ${ }^{\mathrm{TM}}$ Quanta 600F environmental SEM with field emission gun electron source, ETD, and SSD. SE and BSE images were acquired using the ETD (configured with a positively-biased Faraday cage) and SSD, respectively, at 10 mm working distance and 10-20 keV accelerating voltage.

Because EDS elemental analysis showed that SLMs are composed of sulfur-rich carbonaceous material, XANES spectroscopy was used to probe the sulfur K-edge (2472 eV) of SLMs in thin-sections in order to determine their chemical compositions. The experiments were performed at the Stanford Synchrotron Radiation Lightsource (SSRL) on beamline 14-3 utilizing a silicon(110) monochromator crystal; data was collected in fluorescence mode. Gypsum was used as a non-simultaneous calibrant. Linear combination fitting (LCF) of the XANES spectra 
was performed using the SIXPack interface to the IFEFFIT XAFS analysis package (Webb, 2005). Spectra for the model sulfur compounds (cysteic acid, dibenzothiophene, dimethylsulfoxide, elemental sulfur, glutathione-oxidized, gypsum, L-cystine, lipolic acid, marcasite, methionine methylsulfonium chloride, methionine sulfone, methionine, polyphenylene sulfide, pyrite, pyrrhotite, sodium bisulfite, sodium sulfite, sodium thiosulfate, sodium trichloromethane, sphalerite, taurine, thianthrene) were obtained from the ID21 sulfur XANES spectra database (http://www.esrf.eu). In LCF, species were only included which decreased the R value (fit residual) by more than 20\%. In additional to EDS elemental maps acquired via SEM, XRF elemental maps were also generated on beamline 2-3 at the SSRL using a silicon(111) monochromator crystal at $12 \mathrm{keV}$.

\section{Results}

The SLMs most commonly occur within spheroidal to sub-spheroidal phosphatized fossils referable to the putative animal embryo Megasphaera in unit 4A (Xiao and Knoll, 2000). They are distributed randomly within Megasphaera of various developmental stages, including two- and four-cell stages (Fig. 2A,B). Observed in transmitted-light microscopy of petrographic thin-sections, the SLMs appear more opaque than the surrounding cell lumens of Megasphaera, and are usually unbranched and rigid (Fig. 2C,D). However, rare curved and folded SLMs are also present (Fig. 2E,F). The SLMs are often aggregated in terminally-spreading fascicles (Fig. 2B), which are sometimes attached to the cell membranes or envelopes of Megasphaera (Fig. $2 \mathrm{G}, \mathrm{H})$.

Contrast in BSE images indicate that the SLMs are composed of a material with lower average atomic number (Z) than the apatite in the cell lumens (Fig. 3). EDS elemental maps 
acquired via SEM show that this lower-Z material is most likely sulfur-containing carbonaceous material (Fig. 3I-P). Silicon is absent from the SLMs, generally restricted to minerals found in the matrix around Megasphaera. XRF elemental maps—produced with synchrotron X-rays, which interact with samples at greater depths and achieve better energy resolution than EDS maps at the cost of signal heterogeneity in non-homogenous samples—also show that the SLMs contain lower concentrations of silicon and iron, but higher concentrations of sulfur, than the lumen of Megasphaera (Fig. 3E-H). Normalized S K-edge XANES spectra collected via spot analyses of the SLM fascicle (Fig. 3C) and of carbonaceous material located in the matrix around Megasphaera (Fig. 3D) generally show three peaks: a peak at $\sim 2474 \mathrm{eV}$ and relatively less intense peaks at $\sim 2476$ and $\sim 2479 \mathrm{eV}$ (Fig. 4). A fourth peak at $\sim 2483 \mathrm{eV}$ is apparent in some spectra and varies in relative intensity among spots, suggesting that multiple sulfur compounds are present and vary in relative abundance among spots. LCF of representative spectra of SLM fascicle and matrix carbonaceous material to spectra of model sulfur compounds indicates that the best two-compound fits for the SLM fascicle and matrix carbonaceous material spectra are, respectively, dibenzothiophene (DBT, a thiophene common in petroleum; Aizenshtat et al. (1995)) with polyphenylene-sulfide and DBT with gypsum (Table 1). Inclusion of spectra of other compounds (e.g. elemental sulfur and pyrite) in LCF did not significantly improve the fits. Traces of sulfate may be present in apatite surrounding the SLM fascicle and matrix carbonaceous material (Shields et al., 2004), responsible for the peak at $2483 \mathrm{eV}$. The other peaks in the sulfur XANES spectra likely represent organic sulfur in heterocyclic compounds such as DBT, previously reported from organic structures of Precambrian microfossils (Lemelle et al., 2008) and from organic matter in the Dengying Formation (Duda et al., 2014). Thiophenes are abundant in anoxic environments with bacterial sulfate reduction and cyanobacterial mats 
influenced by hydrogen sulfide (Philp et al., 1992), such as the sediment pore waters in which the apatite comprising the phosphatized fossils at Weng'an most likely precipitated (Muscente et al., 2015).

FIB-EM (Fig. 5) and TEM (Fig. 6) revealed that the SLMs are rectangular in transverse sections, lack axial canals, and are composed of homogenous albeit porous carbonaceous material ("pC” in Fig. 5P). Pores in the porous carbonaceous material can be 30 to $100 \mathrm{~nm}$ in diameter, but are typically less than $50 \mathrm{~nm}$ in diameter (Figs. 5P, 6A,J,K). The porous carbonaceous material in the SLMs closely resembles unassociated porous carbonaceous material located in the cell lumen in terms of contrast and porosity ("upC" in Fig. 5P). Neither the rectangular shape nor dimensions of SLM transverse sections changed significantly during ion milling and polishing (Fig. 5K-O). TEM-based EDS elemental mapping of the ultra-thin foil confirms high carbon and sulfur and low silicon, iron, calcium, fluorine, oxygen, and phosphorus concentrations in SLMs relative to surrounding cell lumen (Fig. 6B-I). Silicon and aluminum peaks are limited to an authigenic aluminosilicate located between the carbonaceous material of the SLM and a micrometer-sized apatite crystal (5 $\mu \mathrm{m}$ in diameter; "mA" in Fig. 6A,J,K). SAED analyses corroborate inferences based on electron imaging, EDS, XRF, and XANES, showing that the SLM material weakly scatters electrons throughout reciprocal space (Fig. 6L), and therefore, is generally amorphous. The phosphatic minerals surrounding the SLMs, on the other hand, yield diffraction patterns containing sharp peaks consistent with nanocrystalline (Fig. 6M,N) and microcrystalline (Fig. 6O-Q) apatite.

Three types of apatite mineralization can be observed in the analyzed specimens (Fig. 6). The cell lumen surrounding the SLMs is filled with randomly-oriented apatite nanocrystals ( $\sim .1$ $\mu \mathrm{m}$ diameter; "ncA" in Fig. 6A,J,K). These randomly-oriented apatite nanocrystals are in contact 
with the SLMs in some places. However, they are typically separated from SLMs by voids (possible FIB damage) and isopachous apatite cement of radially-oriented prismatic crystals (0.3-0.6 $\mu$ m diameter; “icA” in Fig. 6A,J,K). The third mineralization type is exemplified by the micrometer-sized apatite crystal that cross-cuts the SLM prepared as an ultra-thin foil ("mA" in Fig. 6A,J,K). Unlike the isopachous apatite cement, which is in contact with porous carbonaceous material, the micrometer-sized apatite crystals is separated from porous carbonaceous material by $0.5 \mu \mathrm{m}$ thick nonporous compressed carbonaceous material (“cC” in Fig. 6A,J,K).

\section{Discussion}

The SLMs in the phosphatized fossils at Weng'an are rectangular in transverse sections and carbonaceous (specifically thiophenic) in composition, and therefore, are not cylindrical siliceous sponge spicules. Although carbonaceous fossils from the lower Cambrian have been interpreted as organic sheaths that originally surrounded siliceous spicules (Harvey, 2010), the SLMs do not appear to be organic sheaths that ever encased spicules. In addition, unlike rigid sponge spicules, curved and folded SLMs imply original flexibility (Fig. 2E,F). Petrographic observations also indicate that the phosphatized fossils containing SLMs do not the match expectancies of demosponge spiculogenesis. Modern siliceous spicules are initially formed within one and later in association with several sclerocytes, but the two- and four-celled Megasphaera (Fig. 2A) that host SLMs do not seem to have had differentiated cell types such as sclerocytes. Putative sclerocytes described from the purported Doushantuo sponges (Li et al., 1998b) resemble subcellular structures interpreted as possible lipid vesicles (Hagadorn et al., 2006; Schiffbauer et al., 2012). 


\subsection{Origin of the spicule-like microstructures}

The SLMs may represent carbonized filamentous bacteria, such as sulfur-oxidizing bacteria filaments, which sometimes have rectangular transverse sections (Lacko et al., 1999). Phosphatic filaments—interpreted as possible bacterial filaments, fungal hyphae, and mucous strands (Xiao and Schiffbauer, 2009)—are found inside and attached to Megasphaera envelopes in unit 4B (Fig. 1), and include forms that are sparsely-branching (15-20 $\mu \mathrm{m}$ diameter), anastomosing (3-5 $\mu \mathrm{m}$ diameter), and coated with botryoidal cements (Fig. 7). The sparselybranching phosphatic filaments sometimes contain axially-located structures (2-7 $\mu \mathrm{m}$ diameter) that are circular or oblong (possibly rectangular) in transverse sections, replicated by radially- or randomly-oriented nanocrystals ( $0.1 \mu \mathrm{m}$ diameter), and coated with radially-oriented prismatic microcrystals ( 0.3 to $2 \mu \mathrm{m}$ diameter). The paragenesis of apatite in phosphatized fossils from unit 4B inferred from SEM observations indicates the axially-located structures were originally organic filaments that were replicated by nanocrystals and then coated with later diagenetic microcrystals, which variously augmented their overall diameters (Cunningham et al., 2012; Schiffbauer et al., 2012; Xiao and Schiffbauer, 2009). Thus, it is possible that SLMs represent an organic version of those phosphatized filaments with an oblong axial structure.

Alternatively, the SLMs may be sponge axial filaments ( $2-5 \mu \mathrm{m}$ in diameter), which in sponge development, are the organic precursors of spicules (Müller et al., 2007). Hexactinellid axial filaments are square in transverse section (Reiswig, 1971), thus broadly resembling the SLMs; in contrast, demosponge axial filaments are triangular (Reiswig, 1971) or hexagonal (Simpson et al., 1985) in transverse section. Axial filaments are generally rare in the fossil record, but are sometimes preserved in mineralized spicules (Botting and Muir, 2013). If the 
SLMs are confirmed to be axial filaments, they could provide evidence of hexactinellids. This possibility, however, does not necessitate that the sponges that produced such axial filaments were biomineralizing organisms, as organic axial filaments could have evolved prior to-and then were exapted for-spiculogenesis.

The occurrence of fascicles of SLMs seems inconsistent with the filamentous bacterium and axial filament interpretations, and invites comparison with acicular mineral aggregates (Yin et al., 2001). Thus, a third possibility is that the SLMs represent acicular minerals that were diagenetically-replaced and molded by organic matter. However, the flexible nature of some SLMs (Fig. 2F) is inconsistent with the acicular mineral interpretation.

Overall, these hypotheses imply that phosphatized fossils containing SLMs at Weng'an are not crown-group demosponges. Indeed, if the SLMs are bacterial filaments or acicular crystals molded by organic matter, the phosphatized fossils containing SLMs may not be sponges. Alternatively, if the SLMs are axial filaments, they must have been produced by hexactinellids, as crown-group demosponges (Reiswig, 1971) and possibly stem-group siliceans (Botting and Muir, 2013) have triangular or hexagonal axial filaments. Despite this possibility, the phosphatized fossils containing the SLMs possess no diagnostic sponge soft tissue characters (Antcliffe et al., 2014). Given these notable ambiguities, placement of the phosphatized fossils with SLMs among sponges is not supported.

\subsection{Taphonomy of SLMs}

Regardless whether the SLMs are bacterial filaments, axial filaments, or pseudomorphs of acicular crystals, their morphology has been modified, both constructively and destructively, by multiple generations of diagenetic phosphatic mineralization. Randomly-oriented apatite 
nanocrystals ("ncA" in Fig. 6A,J,K) in cell lumen likely formed rapidly during degradation of the cytoplasm when nucleation sites were abundant and the supersaturation level was high (Xiao and Schiffbauer, 2009). Cement stratigraphy suggests that SLMs predate the formation of the isopachous apatite cements ("icA" in Fig. 6A,J,K) that constructively encrust SLMs. In contrast, cross-cutting relationship suggests that micrometer-sized apatite crystals ("mA" in Fig. 6A,J,K) played a destructive role; such micrometer-sized crystals in phosphatized fossils are typically interpreted as late diagenetic overgrowth on pre-existing crystals (Cunningham et al., 2012; Schiffbauer et al., 2012; Xiao and Schiffbauer, 2009). As observed in the ultra-thin foil transverse section of an SLM fascicle (Fig. 6), growth of a micrometer-sized apatite crystal into the SLM caused displacement of organic matter, compressing porous carbonaceous material into nonporous compressed carbonaceous material. Assuming the micrometer-sized apatite crystal in the ultra-thin foil transverse section of an SLM fascicle is representative of the diagenetic processes affecting all SLMs, variations among SLMs and SLM fascicles may correspond to permutations of several variables: the rate and amount of diagenetic apatite growth, the direction of apatite growth relative to the axes of SLMs, and the space available for SLM carbonaceous material displacement and compression. This hypothetical relationship between diagenetic apatite growth and SLM fascicle shape requires further testing with comprehensive in situ analytical techniques, such as FIB-EM nanotomography or X-ray computed nanotomography.

\subsection{Implications for other purported Precambrian sponges}

Our conclusions regarding the phosphatized fossils containing SLMs affirm the observation that no unequivocal sponge fossils occur below the Ediacaran-Cambrian boundary (Antcliffe et al., 2014). Chambered body fossils containing silica and carbonate minerals from 
Cryogenian rocks have been interpreted as biomineralizing sponge-grade metazoans (Maloof et al., 2010; Wallace et al., 2014), but they lack spicules and there is no data affirming the biogenicity of the silica and carbonate minerals. For these reasons, placement of the chambered fossils among crown-group sponges is unlikely (Laflamme, 2010), and they may instead be microbial structures (Antcliffe et al., 2014; Wallace et al., 2014). Various other Precambrian aspiculate fossils—such as Cucullus from China (Wang and Wang, 2011), Thectardis from Newfoundland (Sperling et al., 2011), and Ausia from Namibia (McMenamin, 1998)—have been interpreted as sponges based on inferences regarding soft tissue anatomy, biomechanics, and taphonomy. However, such interpretations of aspiculate organisms are inherently subjective, and the affinities of the fossils remain disputed (Antcliffe et al., 2014).

Although spicules are generally considered among the most easily identifiable and most commonly-preserved features of crown-group sponges, reports of spiculate sponges and sponge spicules from the Precambrian remain ubiquitously controversial due, in part, to the poor preservation and inadequate characterization of the fossils. The spicule-like structures associated with the purported spiculate sponges—including Fedomia from Russia (Serezhnikova and Ivantsov, 2007) and Palaeophragmodictya (Gehling and Rigby, 1996) and Coronacollina (Clites et al., 2012) from South Australia—generally lack the siliceous and calcareous biominerals that constitute modern sponge spicules. Instead, the spicule-like structures are preserved, like cooccurring soft tissues, as casts/molds in siliciclastic rock. Consequently, the spicule-like structures may represent casts/molds of diagenetically-dissolved spicules (Gehling and Rigby, 1996) or organic structures (Clites et al., 2012; Serezhnikova and Ivantsov, 2007), which cannot be distinguished in such a preservational state. For this reason, the spicule-like structures on these fossils do not represent diagnostic evidence of biomineralizing sponges. The phosphatized 
fossils containing SLMs in the Doushantuo Formation were previously considered the only Precambrian sponges preserved with mineralized spicules (Li et al., 1998a, b). However, our new data demonstrate that the SLMs are not siliceous sponge spicules. Thus far, no unequivocal biomineralizing sponges have been reported from Precambrian rocks.

Reports of Precambrian spicule-like structures preserved in the absence of soft tissues are common, but typically provide only non-diagnostic petrographic observations. Without detailed mineralogical and ultrastructural data on these structures, interpretations of these fossils as sponge spicules are unconvincing. For instance, the sponge spicules reported from the Noonday Dolomite in Nevada — which may be a basal Ediacaran cap carbonate (Petterson et al., 2011)— have not been illustrated or described in detail (Reitner and Wörheide, 2002), and have been interpreted as inorganically-precipitated acicular crystals (Antcliffe et al., 2014). Similarly, monaxon-like structures from the Neoproterozoic Tindir Group in Alaska and western Canada identified as hexactinellid spicules (Debrenne and Reitner, 2001) have only been superficially described (Allison and Awramik, 1989). Although reports suggest the Tindir Group spicule-like structures were originally hollow and are comparable to chancellorid sclerites (Allison and Awramik, 1989), they have not received sufficient study to affirm sponge affinities. Other problematic hexactinellid spicules have been reported from the Gangolihat Dolomite of India (Tiwari et al., 2000; Tiwari and Pant, 2009). Most of these Gangolihat Dolomite structures are opaque, and thus do not resemble typical siliceous hexactinellid spicules in thin-sections. Previous reports have described no evidence of axial canals in the Gangolihat Dolomite structures. In addition, the Gangolihat Dolomite may be Mesoproterozoic in age (McKenzie et al., 2011). If so, the structures significantly predate the divergence of biomineralizing sponge classes, as estimated from molecular clocks (Erwin et al., 2011; Sperling et al., 2010). Given 
these uncertainties, the Gangolihat Dolomite structures do not represent compelling evidence of Precambrian sponges.

Besides the Doushantuo SLMs, the only other putative sponge spicules explicitly described with axial canals from the Precambrian are putative hexactinellid monaxons and triaxons from the lower Doushantuo Formation (Du and Wang, 2012). EDS analyses indicate these purported hexactinellid spicules are siliceous in composition. However, the structures lack clearly defined axial canals (despite the authors' claim of such features), they are not preserved with soft tissues, previous reports provide no evidence of concentrically-secreted silica layers, and some of these structures shown in thin sections resemble acicular minerals. Thus, they may be abiotic structures formed via silica encrustation or replacement of diagenetic crystals.

Recently, Du et al. (2014) reported putative sponge gemmules containing gemmosclerelike structures from chert nodules of the Doushantuo Formation in the Yangtze Gorges area of South China. They interpreted the gemmosclere-like structures ( $<1$ micron diameter) as siliceous based on the presence of Si as detected by electron probe microanalysis. However, as the authors noted, it is difficult to focus the electron probe onto micrometer-sized structures, and their compositional analysis may be inaccurate. In addition, the authors provided no mineralogical data and no evidence of axial canals, axial symmetries, and concentric growth layers. For these reasons, the gemmosclere-like structures do not represent unequivocal evidence of Precambrian biomineralizing sponges. They may alternatively be Si-bearing acicular crystals.

Integration of these observations from the literature indicates that, although many spiculate sponges and sponge spicules have been reported from Precambrian rocks, none have been comprehensively characterized in terms of their compositional, mineralogical, and morphological characters. Future studies should test of the veracity of these fossils using in situ 
analytical techniques and cogent evaluation criteria. By doing so, such studies may resolve longstanding controversies, test paleobiologically-significant hypotheses, and potentially provide compelling evidence of biomineralizing sponges in the Precambrian. According to Antcliffe et al. (2014), the oldest fossils equivocally attributable to biomineralizing sponges are siliceous stauractines and pentactines in the early Cambrian Soltanief Formation ( 535 Ma) of Iran. Unambiguous hexactines and pentactines have also been described as Hunanospongia from the basal Cambrian Yangjiaping Member of South China (Ding and Qian, 1988), in association with the Protohertzina anabarica-Kaiyangites novilis small shelly fossil assemblage biozone (Steiner et al., 2007). These are among the earliest known, unambiguous sponge spicules by virtue of their diagnostic and clearly-defined symmetries (Antcliffe et al., 2014).

\subsection{Interpreting the Precambrian dearth of biomineralizing sponge fossils}

The conspicuous scarcity (or complete absence) of spiculate sponges and sponge spicules in the Precambrian has important implications for the evolution of animals and the Earth system across the Ediacaran-Cambrian transition. Whereas the perceived paucity of aspiculate sponge fossils may reflect the taphonomic biases against soft-tissue preservation and the paleontological difficulties associated with differentiating such fossils from those of other soft-bodied organisms, the dearth of spiculate sponges and sponge spicules—which should be readily preservable and easily identifiable—is enigmatic, particularly given that molecular clocks (Erwin et al., 2011; Sperling et al., 2010) and sponge-specific biomarkers (Love et al., 2009) suggest the hexactinellid-demosponge divergence and the internal divergence of spiculate demosponges may have occurred in the Cryogenian. Several explanations have been proposed to account for the 
enigma (Sperling et al., 2010). Below, we review these explanations, and provide new hypotheses for the dearth of biomineralizing sponge fossils in Precambrian rocks.

\subsubsection{Biomarkers and molecular clocks}

Perhaps the simplest explanation for the dearth of Precambrian spiculate sponges and sponge spicules is that biomineralizing sponge classes diverged during the early Cambrian, as suggested by the fossil record. If so, this explanation implies that the Cryogenian divergence of silica-biomineralizing sponges based on molecular clocks (Erwin et al., 2011; Sperling et al., 2010) and biomarkers (Love et al., 2009) needs to be re-evaluated.

The detection of abundant 24-isopropylcholestanes in Cryogenian rocks in Oman is taken as evidence for demosponge divergence in the Cryogenian Period or earlier (Love et al., 2009). The demosponge specificity of 24-isopropylcholestanes has been questioned by some authors (Antcliffe, 2013), although a counter argument has been made (Briggs and Summons, 2014). Thus, it remains possible that 24-isopropylcholesterol evolved along the stem leading to crowngroup demosponges (Love et al., 2009; Sperling et al., 2010). If so, then the Cryogenian occurrence of 24-isopropylcholestanes can be used as a minimum age constraint for the demosponge-hexactinellid divergence. However, as pointed out by Antcliffe (2013), the exact age of the Cryogenian 24-isopropylcholestanes from Oman has been miscited by many authors. These 24-isopropylcholestanes are constrained between 645 Ma and 635 Ma according to Antcliffe (2013), rather than 713 Ma as cited by some authors.

Published molecular clock estimates of sponge divergences were calibrated, in part, using the occurrence of Cryogenian 24-isopropylcholestanes in Oman as a calibration point. For example, both Sperling et al. (2010) and Erwin et al. (2011) used the 713 Ma age as a maximum 
age for the origin of crown-group demosponges. Because the Omani 24-isopropylcholestanes are 645-635 Ma and they may predate the origin of crown group demosponges (Love et al., 2009; Sperling et al., 2010), anchoring the divergence of crown-group demosponges using the $713 \mathrm{Ma}$ age, even as a maximum constraint, may overestimate divergence time. It is important to point out, however, that both Sperling et al. (2010) and Erwin et al. (2011) carried out various sensitivity tests including or excluding the 713 Ma calibration point. For example, Erwin et al. (2011) used a Calibrations-Jackknife analysis—comparing molecular clocks randomly generated using various combinations of 12 out of their 24 available calibration points—-to show that their estimated divergence dates of animals, on average, were not significantly affected by their selection of geochronological calibrants and that their analyses consistently supported a Cryogenian divergence of biomineralizing sponge classes (and internal divergence of spiculate demosponges). Nonetheless, the general problem of using stem-group fossils to calibrate their crown-group counterparts remains, and it may be compounded by phylogenetic uncertainties and taxon sampling problems, particularly when the deepest divergence in the crown-group taxon is not represented in the taxon sampling. Thus, considering the significant discrepancy between molecular clocks and skeletal fossils, more effort needs to be spent to improve the accuracy of both records.

\subsubsection{Independent origins of sponge biomineralization in the Cambrian}

Another explanation for the dearth of spiculate sponges and sponge spicules in the Precambrian is that silica biomineralization may have evolved independently among hexactinellids and demosponges during the early Cambrian, perhaps in response to extrinsic ecological and environmental factors driving animal skeletonization (Marshall, 2006; Zhang et 
al., 2014). Given that it is uncertain whether the siliceans are monophyletic and that aspiculate demosponges (e.g., Keratosa and Myxospongiae) either form a sister group to spiculate demosponges or branch successively at the base of the demosponge clade (Hill et al., 2013), it is possible that demosponge biomineralization may have evolved independently of hexactinellids. Although it is more difficult to accept that the heteroscleromorphs and haploscleromorphs evolved siliceous spicules independently (Cárdenas et al., 2012; Sperling et al., 2010), if the Heteroscleromorpha-Haploscleromorpha divergence is overestimated by several tens of millions of years, then it is possible that the common ancestor of heteroscleromorphs and haploscleromorphs evolved biomineralization in the Cambrian rather than Cryogenian-Ediacaran interval. Under such a scenario, silicean biomineralization evolved in the early Cambrian independently among two clades: the hexactinellids and heteroscleromorphs+haploscleromorphs. Recently, however, there has been paleontological evidence suggesting that spicules may be homologous among siliceans or even among siliceans and calcareans (Botting and Butterfield, 2005). It is proposed that ancestral sponges had bimineralic spicules consisting of both silica and calcite, and if sponges are paraphyletic, then the last common ancestor of metazoans may have been spiculate (Botting et al., 2012). Accepting that spicules are homologous among siliceans, sponges, or even metazoans (Botting et al., 2012), and given that there is abundant evidence supporting the appearance of crown-group animals in the Ediacaran Period (Xiao and Laflamme, 2009), it is rather difficult to explain the dearth of Precambrian sponge spicules without invoking a taphonomic megabias against the preservation of Precambrian siliceous spicules.

\subsubsection{Taphonomic megabias}


There are limited data regarding the taphonomic processes governing siliceous spicule preservation. However, multiple studies have characterized factors affecting dissolution of biosilica in diatoms (Cheng et al., 2009; Dixit et al., 2001; Lewin, 1961; Roubeix et al., 2008). In general, the preservation potential of biosilica depends upon its reactive surface area as well as the $\mathrm{pH}$, temperature, salinity, and dissolved silica concentration of the surrounding bottom/pore waters (Van Cappellen and Qiu, 1997a, b). In addition, the presence of organic and inorganic materials impacts biosilica preservation. Organic material as well as inorganic precipitates (e.g. iron or manganese) can absorb onto biosilica, reduce its reactive surface area, and protects it from dissolution (Chu et al., 2011; Lewin, 1961). Similarly, dissolution of aluminosilicate minerals provides aqueous $\mathrm{Al}(\mathrm{III})$, which becomes absorbed onto biosilica, producing negatively-charged aluminosilicate surface sites that reduce interactions with catalytic hydroxyl ions and decrease the solubility of the siliceous material (Cheng et al., 2009; Dixit et al., 2001). Lastly, microbial activity affects biosilica preservation. Experiments using marine bacteria show that bacterial colonization significantly increases biosilica solubility (Bidle and Azam, 1999).

In this context, the impact of the Precambrian-Phanerozoic transition on biosilica preservation can be evaluated. Secular changes in chert precipitation and deposition across the Precambrian-Phanerozoic transition affirm evolving geobiological participation in the silica cycle during this interval (Maliva et al., 1989; Maliva et al., 2005). Modelling suggests that, before the diversification of silica-biomineralizing plankton in the early Phanerozoic, seawater and pore water $\mathrm{SiO}_{2}$ concentrations may have been as high as $60 \mathrm{ppm}$ (Perry and Lefticariu, 2014), roughly ten times higher than modern levels (Racki and Cordey, 2000). Though under these levels $\mathrm{SiO}_{2}$ would have been undersaturated with respect to amorphous silica (Siever, 1992), everything else being equal, biosilica would have been less soluble in Neoproterozoic 
than in Phanerozoic seawater. Additionally, biosilica would have been less soluble in low temperature Cryogenian environments than in younger greenhouse analogues. Hence, changes in seawater silica concentrations and temperatures do not account for the purported megabias.

Because incorporation of Al(III) decreases biosilica solubility, the dearth of siliceous spicules may reflect secular changes in bottom/pore water $\mathrm{Al}(\mathrm{III})$ concentrations through time. For instance, Sperling et al. (2010) hypothesized that siliceous spicules were unlikely to be preserved in clay- and $\mathrm{Al}(\mathrm{III})$-deficient Neoproterozoic sediments, and proposed that an increase in the total clay contents of sediments deposited from 850 to 530 Ma opened a taphonomic window for the preservation of siliceous spicules. However, several observations dispute this hypothesis. First, the authors cite increasing X-ray diffraction peak ratios of phyllosilicates to quartz from 850-530 Ma in three basins as evidence of global trends in the clay contents of sedimentary rocks (Kennedy et al., 2006). However, these ratios do not distinguish between micaceous clays and pedogenic smectite/kaolinite clays. Micaceous clays would not necessarily be a source of $\mathrm{Al}(\mathrm{III})$ in early diagenesis, and hence, should not have factored into the preservation of the siliceous spicules. Second, empirical data derived from additional basins indicate that Neoproterozoic and early Cambrian sedimentary rocks are generally comparable in total clay contents, and exhibit no increase in total clay contents with time (Tosca et al., 2010). Lastly, although micaceous clays dominate most late Neoproterozoic clay mineralogy (Tosca et al., 2010), some Ediacaran successions (e.g., the Doushantuo Formation in the Yangtze Gorges area of South China) have abundant Al-rich smectite clays (Bristow et al., 2009), but preserve no siliceous sponge spicules.

Given the effect of marine bacteria on biosilica dissolution, the transition from Precambrian seafloors with well-developed microbial mats to Phanerozoic-type sediments 
characterized by greater vertical mixing (Bottjer et al., 2000; Droser et al., 2002) could partially explain the dearth of siliceous sponge spicules. In modern settings, bacteria colonize and hydrolyze the surface mucus membranes of diatoms (Smith et al., 1995), which denudes the siliceous skeletons of their organic coating, thereby significantly increasing their reactive surface area and solubility (Bidle and Azam, 1999). Microbial mats may have analogously colonized siliceous spicules on Neoproterozoic seafloors, degrading their external organic sheaths (Botting et al., 2012; Harvey, 2010) and the carbonaceous matter absorbed onto their surfaces, thereby enhancing the solubility of the biosilica. In addition, organisms inhabiting microbial mats in proximity to siliceous spicules may have-through their various activities (Callow and Brasier, 2009; Muscente et al., 2015)—modified biosilica dissolution.

Hypothetically, sponge paleoecology could also account for the dearth of spiculate sponges and sponge spicules in the Precambrian. Several key observations of modern sponge ecology and spiculogenesis suggest that, during the Precambrian, spiculate sponges may have been more ecological restricted and may have produced small or weakly-mineralized spicules, which may have been rapidly dissolved. First, spicules protect modern sponges from predators (Burns et al., 2003; Hill et al., 2005; Jones et al., 2005), suggesting that predation may have driven the evolution of spicules. If so, spiculate sponges in the Neoproterozoic may have-in the absence of predatory animals_-produced ostensibly small spicules with low preservational potential. Only after the diversification of predatory animals during the Cambrian Explosionwhen large spicules may have enabled sponges to deter the predators—may extensive biomineralization have become widespread among sponges. Second, due to the energydependence of silica transport and sclerocyte production (Frøhlich and Barthel, 1997), environmental nutrient availability affects spicule size and morphology (Liu et al., 2013). 
Sponges in oligotrophic environments typically form smaller spicules than analogues inhabiting eutrophic settings (Bibiloni et al., 1989), and starvation causes sponges to significantly reduce and sometimes cease spicule production (Frøhlich and Barthel, 1997; Pe 1973). Because of this relationship between nutrient availability and spiculogenesis, widespread marine anoxia in Proterozoic oceans may have restricted the ecological distribution of spiculate sponges. In addition, although sponges can survive in dysoxic environments (Mills et al., 2014)—such as those that likely exited in Proterozoic oceans - they tend to produce smaller spicules when oxygen levels are low (Liu et al., 2013). Lastly, low oxygen availability is also associated with low levels of predation (Sperling et al., 2013). Consequently, sponges inhabiting Proterozoic oceans with lower oxygen levels than the present may not have experienced predation pressures that drive evolution of extensive biomineralized skeletons. Overall, these various observations suggest that Neoproterozoic spiculate sponges may have been more ecologically restricted and produced smaller spicules than their Phanerozoic descendants. If so, the evolution of sponges with larger, more easily-preserved spicules may have been promoted by secular change in nutrient availability, the progressive oxygenation of the ocean, and the diversification of predatory animals through the Cryogenian-Cambrian interval (Canfield et al., 2007; Lenton et al., 2014; Sahoo et al., 2012).

\section{Conclusions}

In summary, we have demonstrated that in situ analytical techniques_including SEM, FIB-EM, TEM, EDS, XRF, and XANES—can be used to decisively assess the veracity of putative Precambrian sponge fossils. Our analysis shows that SLMs occurring within phosphatized fossils from the Doushantuo Formation at Weng'an in South China are organic 
filaments with rectangular transverse cross-sections, and therefore, are not cylindrical siliceous sponge spicules. This conclusion invalidates the descriptions of the oldest demosponges in the fossil record and of the only Precambrian sponges purportedly preserved with mineralized spicules (Li et al., 1998a, b). These results have notable implications for the Precambrian record of sponges. In particular, the analytical techniques in this study represent useful tools to critically assess the veracity of other problematic sponge fossils, specifically those with putative biominerals (Allison and Awramik, 1989; Du and Wang, 2012; Du et al., 2014; Maloof et al., 2010; Reitner and Wörheide, 2002; Tiwari et al., 2000; Wallace et al., 2014). By using the analytical techniques to collect in situ compositional, mineralogical, and ultrastructural data on these fossils, future studies may resolve long-standing controversies, test paleobiologicallysignificant hypotheses, and potentially provide compelling evidence of biomineralizing sponges in Precambrian rocks. Thus far, no Precambrian sponge fossils have been demonstrated to have decisive mineralogical and morphological characters in support of biomineralization. Thus, molecular clock data suggesting that spiculate sponges diverged in the Cryogenian and Ediacaran periods need to be scrutinized more closely. If biomineralizing sponge clades did diverge in the Cryogenian-Ediacaran periods, as suggested by molecular clocks and biomarkers (Erwin et al., 2011; Love et al., 2009; Sperling et al., 2010), then we have to consider the possibility of independent origins of biomineralized spicules or a taphonomic megabias. A number of factors—including low sediment pedogenic clay mineral content, prevalence of microbial mats, low predation pressures, low nutrient availability, and oceanic anoxia—may have fostered spicule miniaturization and dissolution in the Neoproterozoic. If so, the molecular and fossil records may represent unique albeit complementary windows to sponge evolutionary history. Whereas molecular clocks may record the timing and pace of sponge cladogenesis, the fossil 
record (or lack thereof) may reflect the ecological success, distribution, and preservation of early sponges in Precambrian environments. Regardless, the dearth of biomineralizing sponge fossils before the Cambrian represents a geobiologically significant aspect of the ProterozoicPhanerozoic transition, and merits detailed investigation.

\section{Acknowledgements}

This work was supported by grants from the National Science Foundation (EAR-1250800) to S.X., Geological Society of America, Sigma Xi Scientific Research Society, and Virginia Tech Graduate Student Assembly to A.D.M, and Virginia Tech Department of Geosciences to A.D.M. and F.M.M. Use of the Stanford Synchrotron Radiation Lightsource, SLAC National Accelerator Laboratory, is supported by the U.S. Department of Energy, Office of Science, Office of Basic Energy Sciences under Contract No. DE-AC02-76SF00515. We thank B. Kocar, S. Webb, and the personnel at the SRRL for assistance in XANES and XRF analyses. Also, S. McCartney, M. Meyer, J. Tuggle, and C. Winkler are acknowledged for assistance in electron microscopy. We additionally thank James D. Schiffbauer and Erik Sperling for critical comments that greatly helped us to improve the quality of this report.

\section{References}

Aizenshtat, Z., Krein, E.B., Vairavamurthy, M., A., Goldstein, T.P., 1995. Role of Sulfur in the Transformations of Sedimentary Organic Matter: A Mechanistic Overview, in: Vairavamurthy, M.A., Schoonen, M.A.A., Eglinton, T.I., Luther III, G.W., Manowitz, B. (Eds.), Geochemical Transformations of Sedimentary Sulfur. American Chemical Society, pp. 16-37. 
Allison, C.W., Awramik, S.M., 1989. Organic-walled microfossils from earliest Cambrian or latest proterozoic Tindir Group rocks, Northwest Canada. Precambrian Research 43, 253-294.

Antcliffe, J.B., 2013. Questioning the evidence of organic compounds called sponge biomarkers. Palaeontology 56, 917-925.

Antcliffe, J.B., Callow, R.H.T., Brasier, M.D., 2014. Giving the early fossil record of sponges a squeeze. Biological Reviews, 10.1111/brv.12090.

Barfod, G.H., Albaréde, F., Knoll, A.H., Xiao, S., Télouk, P., Frei, R., Baker, J., 2002. New Lu$\mathrm{Hf}$ and $\mathrm{Pb}-\mathrm{Pb}$ age constraints on the earliest animal fossils. Earth and Planetary Science Letters 201, 203-212.

Bibiloni, M.A., Uriz, M.J., Gili, J.M., 1989. Sponge communities in three submarine caves of the balearic islands (western Mediterranean): Adaptations and faunistic composition. Marine Ecology 10, 317-334.

Bidle, K.D., Azam, F., 1999. Accelerated dissolution of diatom silica by marine bacterial assemblages. Nature 397, 508-512.

Botting, J.P., Butterfield, N.J., 2005. Reconstructing early sponge relationships by using the Burgess Shale fossil Eiffelia globosa, Walcott. Proceedings of the National Academy of Sciences, USA 102, 1554-1559.

Botting, J.P., Muir, L.A., 2013. Spicule structure and affinities of the Late Ordovician hexactinellid-like sponge Cyathophycus loydelli from the Llanfawr Mudstones Lagerstätte, Wales. Lethaia 46, 454-469. 
Botting, J.P., Muir, L.A., Xiao, S., Li, X., Lin, J.-P., 2012. Evidence for spicule homology in calcareous and siliceous sponges: biminerallic spicules in Lenica sp. from the Early Cambrian of South China. Lethaia 45, 463-475.

Bottjer, D.J., Hagadorn, J.W., Dornbos, S.Q., 2000. The Cambrian substrate revolution. GSA Today $10,1-7$.

Brasier, M., Green, O., Shields, G., 1997. Ediacarian sponge spicule clusters from southwestern Mongolia and the origins of the Cambrian fauna. Geology 25, 303-306.

Briggs, D.E.G., Summons, R.E., 2014. Ancient biomolecules: Their origins, fossilization, and role in revealing the history of life. BioEssays 36, 482-490.

Bristow, T.F., Kennedy, M.J., Derkowski, A., Droser, M.L., Jiang, G., Creaser, R.A., 2009. Mineralogical constraints on the paleoenvironments of the Ediacaran Doushantuo Formation. Proceedings of the National Academy of Sciences, USA 106, 13190-13195.

Brocks, J.J., Butterfield, N.J., 2009. Early animals out in the cold. Nature 457, 672-673.

Burns, E., Ifrach, I., Carmeli, S., Pawlik, J.R., Ilan, M., 2003. Comparison of anti-predatory defenses of Red Sea and Caribbean sponges. I. Chemical defense. Marine Ecology Progress Series 252, 105-114.

Callow, R.H.T., Brasier, M.D., 2009. Remarkable preservation of microbial mats in Neoproterozoic siliciclastic settings: Implications for Ediacaran taphonomic models. Earth-Science Reviews 96, 207-219.

Canfield, D.E., Poulton, S.W., Narbonne, G.M., 2007. Late-Neoproterozoic deep-ocean oxygenation and the rise of animal life. Science 315, 92-95. 
Cárdenas, P., Pérez, T., Boury-Esnault, N., 2012. Chapter two - Sponge Systematics Facing New Challenges, in: Mikel A. Becerro, M.J.U.M.M., Xavier, T. (Eds.), Advances in Marine Biology. Academic Press, pp. 79-209.

Chen, D., Dong, W., Zhu, B., Chen, X.P., 2004. Pb-Pb ages of Neoproterozoic Doushantuo phosphorites in South China: Constraints on early metazoan evolution and glaciation events. Precambrian Research 132, 123-132.

Chen, L., Xiao, S., Pang, K., Zhou, C., Yuan, X., 2014. Cell differentiation and germ-soma separation in Ediacaran animal embryo-like fossils. Nature advance online publication.

Chen, Z., Zhou, C., Meyer, M., Xiang, K., Schiffbauer, J.D., Yuan, X., Xiao, S., 2013. Trace fossil evidence for Ediacaran bilaterian animals with complex behaviors. Precambrian Research 224, 690-701.

Cheng, T., Hammond, D.E., Berelson, W.M., Hering, J.G., Dixit, S., 2009. Dissolution kinetics of biogenic silica collected from the water column and sediments of three Southern California borderland basins. Marine Chemistry 113, 41-49.

Chu, J.W.F., Maldonado, M., Yahel, G., Leys, S.P., 2011. Glass sponge reefs as a silicon sink. Marine Ecology Progress Series 441, 1-14.

Clites, E.C., Droser, M.L., Gehling, J.G., 2012. The advent of hard-part structural support among the Ediacara biota: Ediacaran harbinger of a Cambrian mode of body construction. Geology 40, 307-310.

Condon, D., Zhu, M., Bowring, S., Wang, W., Yang, A., Jin, Y., 2005. U-Pb ages from the Neoproterozoic Doushantuo Formation, China. Science 308, 95-98.

Cunningham, J.A., Thomas, C.-W., Bengtson, S., Kearns, S.L., Xiao, S., Marone, F., Stampanoni, M., Donoghue, P.C.J., 2012. Distinguishing geology from biology in the 
Ediacaran Doushantuo biota relaxes constraints on the timing of the origin of bilaterians. Proceedings of the Royal Society B: Biological Sciences 279, 2369-2376.

Debrenne, F., Reitner, J., 2001. Sponges, cnidarians, and ctenophores, in: Zhuravlev, A.Y., Riding, R. (Eds.), The Ecology of the Cambrian Radiation. Columbia University Press, New York, pp. 301-325.

Ding, W., Qian, Y., 1988. Late Sinian to Early Cambrian small shelly fossils from Yangjiaping, Shimen, Hunan. Acta Micropalaeontologica Sinica 5, 39-55.

Dixit, S., Van Cappellen, P., van Bennekom, A.J., 2001. Processes controlling solubility of biogenic silica and pore water build-up of silicic acid in marine sediments. Marine Chemistry 73, 333-352.

Dornbos, S.Q., Bottjer, D.J., Chen, J.Y., Gao, F., Oliveri, P., Li, C.W., 2006. Environmental controls on the taphonomy of phosphatized animals and animal embryos from the Neoproterozoic Doushantuo Formation, southwest China. Palaios 21, 3-14.

Droser, M.L., Jensen, S., Gehling, J.G., 2002. Trace fossils and substrates of the terminal Proterozoic-Cambrian transition: Implications for the record of early bilaterians and sediment mixing. Proceedings of the National Academy of Sciences, USA 99, 1257212576.

Du, W., Wang, X.L., 2012. Hexactinellid sponge spicules in Neoproterozoic dolostone from South China. Paleontological Research 16, 199-207.

Du, W., Wang, X.L., Komiya, T., 2014. Potential ediacaran sponge gemmules from the Yangtze Gorges area in South China. Gondwana Research, published online.

DOI:10.1016/j.gr.2014.08.012. 
Duda, J.-P., Blumenberg, M., Thiel, V., Simon, K., Zhu, M., Reitner, J., 2014. Geobiology of a palaeoecosystem with Ediacara-type fossils: The Shibantan Member (Dengying Formation, South China). Precambrian Research 255, 48-62.

Erwin, D.H., Laflamme, M., Tweedt, S.M., Sperling, E.A., Pisani, D., Peterson, K.J., 2011. The Cambrian conundrum: Early divergence and later ecological success in the early history of animals. Science 334, 1091-1097.

Frøhlich, H., Barthel, D., 1997. Silica uptake of the marine sponge Halichondria panicea in Kiel Bight. Marine Biology 128, 115-125.

Gehling, J.G., Rigby, J.K., 1996. Long expected sponges from the Neoproterozoic Ediacara fauna of South Australia. Journal of Paleontology 70, 185-195.

Gehling, J.G., Runnegar, B.N., Droser, M.L., 2014. Scratch traces of large Ediacara bilaterian animals. Journal of Paleontology 88, 284-298.

Hagadorn, J.W., Xiao, S., Donoghue, P.C.J., Bengtson, S., Gostling, N.J., Pawlowska, M., Raff, E.C., Raff, R.A., Turner, F.R., Yin, C., Zhou, C., Yuan, X., McFeely, M.B., Stampanoni, M., Nealson, K.H., 2006. Cellular and subcellular structure of Neoproterozoic embryos. Science 314, 291-294.

Harvey, T.H.P., 2010. Carbonaceous preservation of Cambrian hexactinellid sponge spicules. Biology Letters 6, 834-837.

Hill, M.S., Hill, A.L., Lopez, J., Peterson, K.J., Pomponi, S., Diaz, M.C., Thacker, R.W., Adamska, M., Boury-Esnault, N., Cárdenas, P., Chaves-Fonnegra, A., Danka, E., De Laine, B.-O., Formica, D., Hajdu, E., Lobo-Hajdu, G., Klontz, S., Morrow, C.C., Patel, J., Picton, B., Pisani, D., Pohlmann, D., Redmond, N.E., Reed, J., Richey, S., Riesgo, A., Rubin, E., Russell, Z., Rützler, K., Sperling, E.A., di Stefano, M., Tarver, J.E., Collins, 
A.G., 2013. Reconstruction of family-level phylogenetic relationships within Demospongiae (Porifera) using nuclear encoded housekeeping genes. PLoS ONE 8, e50437.

Hill, M.S., Lopez, N.A., Young, K.A., 2005. Anti-predator defenses in western North Atlantic sponges with evidence of enhanced defense through interactions between spicules and chemicals. Marine Ecology Progress Series 291, 93-102.

Hoffman, P.F., Li, Z.-X., 2009. A palaeogeographic context for Neoproterozoic glaciation. Palaeogeography Palaeoclimatology Palaeoecology 277, 158-172.

Hua, H., Chen, Z., Yuan, X., Zhang, L., Xiao, S., 2005. Skeletogenesis and asexual reproduction in the earliest biomineralizing animal Cloudina. Geology 33, 277-280.

Jiang, G., Shi, X., Zhang, S., Wang, Y., Xiao, S., 2011. Stratigraphy and paleogeography of the Ediacaran Doushantuo Formation (ca. 635-551 Ma) in South China. Gondwana Research 19, 831-849.

Jones, A.C., Blum, J.E., Pawlik, J.R., 2005. Testing for defensive synergy in Caribbean sponges: Bad taste or glass spicules? Journal of Experimental Marine Biology and Ecology 322, $67-81$.

Kennedy, M., Droser, M., Mayer, L.M., Pevear, D., Mrofka, D., 2006. Late Precambrian oxygenation: inception of the clay mineral factory. Science 311, 1446-1449.

Lacko, N., Bux, F., Kasan, H.C., 1999. Survey of filamentous bacteria in activated sludge plants in KwaZulu-Natal. Water SA 25, 63-68.

Laflamme, M., 2010. Palaeontology: Wringing out the oldest sponges. Nature Geoscience 3, $597-598$. 
Lemelle, L., Labrot, P., Salomé, M., Simionovici, A., Viso, M., Westall, F., 2008. In situ imaging of organic sulfur in 700-800 My-old Neoproterozoic microfossils using X-ray spectromicroscopy at the S K-edge. Organic Geochemistry 39, 188-202.

Lenton, T.M., Boyle, R.A., Poulton, S.W., Shields-Zhou, G.A., Butterfield, N.J., 2014. Coevolution of eukaryotes and ocean oxygenation in the Neoproterozoic era. Nature Geoscience 7, 257-265.

Lewin, J.C., 1961. The dissolution of silica from diatom walls. Geochimica et Cosmochimica Acta 21, 182-198.

Li, C.-W., Chen, J.-Y., Hua, T.-E., 1998a. Interpreting late Precambrian microfossils: Response. Science 282, 1783a.

Li, C.-W., Chen, J.-Y., Hua, T.-E., 1998b. Precambrian sponges with cellular structures. Science 279, 879-882.

Liu, G., Feng, Q., Shen, J., Yu, J., He, W., Algeo, T.J., 2013. Decline of siliceous sponges and spicule miniaturization induced by marine productivity collapse and expanding anoxia during the Permian-Triassic crisis in South China. Palaios 28, 664-679.

Love, G.D., Grosjean, E., Stalvies, C., Fike, D.A., Grotzinger, J.P., Bradley, A.S., Kelly, A.E., Bhatia, M., Meredith, W., Snape, C.E., Bowring, S.A., Condon, D.J., Summons, R.E., 2009. Fossil steroids record the appearance of Demospongiae during the Cryogenian Period. Nature 457, 718-721.

Maliva, R.G., Knoll, A.H., Siever, R., 1989. Secular change in chert distribution: a reflection of evolving biological particpation in the silica cycle. Palaios 4, 519-532. 
Maliva, R.G., Knoll, A.H., Simonson, B.M., 2005. Secular change in the Precambrian silica cycle: Insights from chert petrology. Geological Society of America Bulletin 117, 835845.

Maloof, A.C., Rose, C.V., Beach, R., Samuels, B.M., Calmet, C.C., Erwin, D.H., Poirier, G.R., Yao, N., Simons, F.J., 2010. Possible animal-body fossils in pre-Marinoan limestones from South Australia. Nature Geoscience 3, 653-659.

Marshall, C.R., 2006. Explaining the Cambrian “explosion” of animals. Annual Review of Earth and Planetary Sciences 34, 355-384.

McKenzie, N.R., Hughes, N.C., Myrow, P.M., Xiao, S., Sharma, M., 2011. Correlation of Precambrian-Cambrian sedimentary successions across northern India and the utility of isotopic signatures of Himalayan lithotectonic zones. Earth and Planetary Science Letters 312, 471-483.

McMenamin, M.A.S., 1998. The Garden of Ediacara: Discovering the First Complex Life. Columbia University Press, New York.

Mills, D.B., Ward, L.M., Jones, C., Sweeten, B., Forth, M., Treusch, A.H., Canfield, D.E., 2014. Oxygen requirements of the earliest animals. Proceedings of the National Academy of Sciences, USA 111, 4168-4172.

Müller, W.E.G., Boreiko, A., Wang, X., Belikov, S.I., Wiens, M., Grebenjuk, V.A., Schloßmacher, U., Schröder, H.C., 2007. Silicateins, the major biosilica forming enzymes present in demosponges: Protein analysis and phylogenetic relationship. Gene 395, 62-71.

Muscente, A.D., Hawkins, A.D., Xiao, S., 2015. Fossil preservation through phosphatization and silicification in the Ediacaran Doushantuo Formation (South China): a comparative 
synthesis. Palaeogeography, Palaeoclimatology, Palaeoecology, published online. DOI:10.1016/j.palaeo.2014.10.013.

Muscente, A.D., Xiao, S., accepted. Resolving three-dimensional and subsurficial features of carbonaceous compressions and shelly fossils using backscattered electron scanning electron microscopy (BSE-SEM). Palaios.

Pe , J., 1973. Etude quantitative de la regulation du squelette chez une eponge d'eau douce. Archives de Biologie 84, 147-173.

Penny, A.M., Wood, R., Curtis, A., Bowyer, F., Tostevin, R., Hoffman, K.-H., 2014. Ediacaran metazoan reefs from the Nama Group, Namibia. Science 344, 1504-1506.

Perry, E.C., Lefticariu, L., 2014. 9.5 - Formation and Geochemistry of Precambrian Cherts, in: Turekian, H.D.H.K. (Ed.), Treatise on Geochemistry (Second Edition). Elsevier, Oxford, pp. 113-139.

Petterson, R., Prave, A.R., Wernicke, B.P., Fallick, A.E., 2011. The Neoproterozoic Noonday Formation, Death Valley region, California. Geological Society of America Bulletin 123, $1317-1336$.

Philp, R.P., Suzuki, N., Galvez-Sinibaldi, A., 1992. Early-stage incorporation of sulfur into protokerogens and possible kerogen precursors, in: Whelan, J., Farrington, J.W. (Eds.), Organic matter: productivity, accumulation, and preservation in recent and ancient sediments. Columbia University Press, New York, USA, pp. 264-282.

Racki, G., Cordey, F., 2000. Radiolarian palaeoecology and radiolarites: Is the present the key to the past? Earth-Science Reviews 52, 83-120.

Reiswig, H.M., 1971. The axial symmetry of sponge spicules and its phylogenetic significance. Cahiers de Biologie Marine 12, 505-514. 
Reitner, J., Wörheide, G., 2002. Non-Lithistid fossil Demospongiae—Origins of their palaeobiodiversity and highlights in history of preservation, in: Hooper, J.N.A., Van Soest, R.W.M., Willenz, P. (Eds.), Systema Porifera. Springer US, pp. 52-68.

Roubeix, V., Becquevort, S., Lancelot, C., 2008. Influence of bacteria and salinity on diatom biogenic silica dissolution in estuarine systems. Biogeochemistry 88, 47-62.

Sahoo, S.K., Planavsky, N.J., Kendall, B., Wang, X., Shi, X., Scott, C., Anbar, A.D., Lyons, T.W., Jiang, G., 2012. Ocean oxygenation in the wake of the Marinoan glaciation. Nature 489, 546-549.

Schiffbauer, J.D., Xiao, S., 2009. Novel application of focused ion beam electron microscopy (FIB-EM) in the preparation and analysis of microfossil ultrastructures. Palaios 24, 616626.

Schiffbauer, J.D., Xiao, S., Sen Sharma, K., Wang, G., 2012. The origin of intracellular structures in Ediacaran metazoan embryos. Geology 40, 223-226.

Serezhnikova, E.A., 2007. Palaeophragmodictya spinosa sp. nov., a bilateral benthic organism from the Vendian of the Southeastern White Sea Region. Paleontol. J. 41, 360-369.

Serezhnikova, E.A., Ivantsov, A.Y., 2007. Fedomia mikhaili-A new spicule-bearing organism of sponge grade from the Vendian (Ediacaran) of the White Sea, Russia. Palaeoworld 16, 319-324.

Shields, G., Kimura, H., Yang, J., Gammon, P., 2004. Sulphur isotopic evolution of Neoproterozoic-Cambrian seawater: New francolite-bound sulphate $\mathrm{d}^{34} \mathrm{~S}$ data and a critical appraisal of the existing record. Chemical Geology 204, 163-182.

Siever, R., 1992. The silica cycle in the Precambrian. Geochimica et Cosmochimica Acta 56, 3265-3272. 
Simpson, T.L., Langenbruch, P.-F., Scalera-Liaci, L., 1985. Silica spicules and axial filaments of the marine sponge Stelletta grubii (Porifera, Demospongiae). Zoomorphology 105, 375382.

Smith, D.C., Steward, G.F., Long, R.A., Azam, F., 1995. Bacterial mediation of carbon fluxes during a diatom bloom in a mesocosm. Deep Sea Research Part II: Topical Studies in Oceanography 42, 75-97.

Sperling, E.A., Frieder, C.A., Raman, A.V., Girguis, P.R., Levin, L.A., Knoll, A.H., 2013. Oxygen, ecology, and the Cambrian radiation of animals. Proceedings of the National Academy of Sciences 110, 13446-13451.

Sperling, E.A., Peterson, K.J., Laflamme, M., 2011. Rangeomorphs, Thectardis (Porifera?) and dissolved organic carbon in the Ediacaran oceans. Geobiology 9, 24-33.

Sperling, E.A., Robinson, J.M., Pisani, D., Peterson, K.J., 2010. Where's the glass? Biomarkers, molecular clocks, and microRNAs suggest a 200-Myr missing Precambrian fossil record of siliceous sponge spicules. Geobiology 8, 24-36.

Steiner, M., Li, G., Qian, Y., Zhu, M., Erdtmann, B.-D., 2007. Neoproterozoic to early Cambrian small shelly fossil assemblages and a revised biostratigraphic correlation of the Yangtze Platform (China). Palaeogeography, Palaeoclimatology, Palaeoecology 254, 67-99.

Steiner, M., Mehl, D., Reitner, J., Erdtmann, B.-D., 1993. Oldest entirely preserved sponges and other fossils from the lowermost Cambrian and a new facies reconstruction of the Yangtze Platform (China). Berliner Geowissenschaftliche Abhandlungen (E) 9, 293-329.

Tiwari, M., Pant, C.C., Tewari, V.C., 2000. Neoproterozoic sponge spicules and organic-walled microfossils from the Gangolihat Dolomite, Lesser Himalaya, India. Current Science 79, $651-654$. 
Tiwari, M., Pant, I., 2009. Microfossils from the Neoproterozoic Gangolihat Formation, Kumaun Lesser Himalaya: Their stratigraphic and evolutionary significance. Journal of Asian Earth Sciences 35, 137-149.

Tosca, N.J., Johnston, D.T., Mushegian, A., Rothman, D.H., Summons, R.E., Knoll, A.H., 2010. Clay mineralogy, organic carbon burial, and redox evolution in Proterozoic oceans. Geochimica et Cosmochimica Acta 74, 1579-1592.

Van Cappellen, P., Qiu, L., 1997a. Biogenic silica dissolution in sediments of the Southern Ocean. I. Solubility. Deep Sea Research Part II: Topical Studies in Oceanography 44, $1109-1128$.

Van Cappellen, P., Qiu, L., 1997b. Biogenic silica dissolution in sediments of the Southern Ocean. II. Kinetics. Deep Sea Research Part II: Topical Studies in Oceanography 44, $1129-1149$.

Wacey, D., Saunders, M., Roberts, M., Menon, S., Green, L., Kong, C., Culwick, T., Strother, P., Brasier, M.D., 2014. Enhanced cellular preservation by clay minerals in 1 billion-yearold lakes. Scientific Reports 4, DOI:10.1038/srep05841.

Wallace, M.W., Hood, A.v.S., Woon, E.M.S., Hoffmann, K.-H., Reed, C.P., 2014. Enigmatic chambered structures in Cryogenian reefs: The oldest sponge-grade organisms? Precambrian Research 255, 109-123.

Wang, Y., Wang, X., 2011. New observations on Cucullus Steiner from the Neoproterozoic Doushantuo Formation of Guizhou, South China. Lethaia 44, 275-286.

Webb, S.M., 2005. SIXpack: a graphical user interface for XAS analysis using IFEFFIT. Physica Scripta 2005, 1011-1014. 
Xiao, S., Hu, J., Yuan, X., Parsley, R.L., Cao, R., 2005. Articulated sponges from the Lower Cambrian Hetang Formation in southern Anhui, South China: their age and implications for the early evolution of sponges. Palaeogeography Palaeoclimatology Palaeoecology 220, 89-117.

Xiao, S., Knoll, A.H., 1999. Fossil preservation in the Neoproterozoic Doushantuo phosphorite Lagerstätte, South China. Lethaia 32, 219-240.

Xiao, S., Knoll, A.H., 2000. Phosphatized animal embryos from the Neoproterozoic Doushantuo Formation at Weng'an, Guizhou, South China. Journal of Paleontology 74, 767-788.

Xiao, S., Knoll, A.H., Yuan, X., Pueschel, C.M., 2004. Phosphatized multicellular algae in the Neoproterozoic Doushantuo Formation, China, and the early evolution of florideophyte red algae. American Journal of Botany 91, 214-227.

Xiao, S., Laflamme, M., 2009. On the eve of animal radiation: Phylogeny, ecology and evolution of the Ediacara biota. Trends in Ecology \& Evolution 24, 31-40.

Xiao, S., Muscente, A.D., Chen, L., Zhou, C., Schiffbauer, J.D., Wood, A.D., Polys, N.F., Yuan, X., 2014a. The Weng'an biota and the Ediacaran radiation of multicellular eukaryotes. National Science Review 1, 498-520.

Xiao, S., Schiffbauer, J.D., 2009. Microfossil Phosphatization and Its Astrobiological Implications, in: Seckbach, J., Walsh, M. (Eds.), From Fossils to Astrobiology: Record of Life on Earth and Search for Extraterrestrial Biosignatures. Springer Netherlands, pp. 89117.

Xiao, S., Zhang, Y., Knoll, A.H., 1998. Three-dimensional preservation of algae and animal embryos in a Neoproterozoic phosphorite. Nature 391, 553-558. 
Xiao, S., Zhou, C., Liu, P., Wang, D., Yuan, X., 2014b. Phosphatized acanthomorphic acritarchs and related microfossils from the Ediacaran Doushantuo Formation at Weng'an (South China) and their implications for biostratigraphic correlation. Journal of Paleontology 88, 1-67.

Yin, L., Xiao, S., Yuan, Y., 2001. New observations on spicule-like structures from Doushantuo phosphorites at Weng'an, Guizhou Province. Chin.Sci.Bull. 46, 1828-1832.

Zhang, S., Jiang, G., Han, Y., 2008. The age of the Nantuo Formation and Nantuo glaciation in South China. Terra Nova 20, 289-294.

Zhang, X., Shu, D., Han, J., Zhang, Z., Liu, J., Fu, D., 2014. Triggers for the Cambrian explosion: Hypotheses and problems. Gondwana Research 25, 896-909.

Zhang, Y., Yuan, X., Yin, L., 1998. Interpreting late Precambrian microfossils. Science 282, 1783.

Zhou, C., Yuan, X., Xue, Y., 1998. Sponge spicule-like pseudofossils from the Neoproterozoic Doushantuo Formation in Weng'an, Guizhou, China. Acta Micropalaeontologica Sinica 15, 380-384.

Zhu, M., Zhang, J., Yang, A., 2007. Integrated Ediacaran (Sinian) chronostratigraphy of South China. Palaeogeography Palaeoclimatology Palaeoecology 254, 7-61.

Fig. 1. Geological background of the Doushantuo Formation at Weng'an, Guizhou Province, South China. (A) Geological map of the Weng'an area. (B) Generalized stratigraphy of Doushantuo Formation at Weng'an. Units 4A and 4B represent the fossiliferous black and gray facies, respectively. Modified from Xiao et al. (2014b). 
Fig. 2. Transmitted-light microscopy of Doushantuo SLMs in petrographic thin-sections. Arrows in (A, C, E, G) indicate areas magnified in (B, D, F, H), respectively. (A) Four-cell Megasphaera. (B) Individual SLM (right), SLM fascicle (left), and ellipsoidal sclerocyte-like structures (Li et al., 1998b) interpreted as lipid vesicles (Hagadorn et al., 2006; Schiffbauer et al., 2012). (C) One-celled Megasphaera. (D) Relatively thick SLM. Black arrow in (D) indicates location of FIB-EM transverse section illustrated in Fig. 5P. (E) Poorly-preserved spheroidal fossil. (F) SLMs with curved morphologies. (G) Megasphaera fossil. (H) SLM fascicle attached to its membrane or envelope. (C, G) are composite transmitted-light images, each assembled from two higher-magnification images (separated by the white lines).

Fig. 3. SEM, EDS, and XRF of SLM fascicle. (A) SEM (SSD) image of Megasphaera illustrated in Fig. 2G. (B) Magnified SEM (SSD) image of SLM fascicle (upper box in A). (C) Magnified image of boxed area in (B), showing the area of the SLM fascicle in (B) that was analyzed with XANES. (D) Magnified image (lower box in A), showing carbonaceous material in matrix around Megasphaera analyzed with XANES. (E-H) XRF elemental maps with color scale below (B) showing relative number of counts (x, minimum number of counts; $y$, maximum number of counts). (E) Sulfur ( $x<36$ counts; $y>141$ counts); (F) Calcium ( $<5596$ counts, $y>9326$ counts); (G) Silicon ( $<38$ counts, $y>149$ counts); (H) Phosphorus (x <110 counts, $y>274$ counts). (I-P) SEM-based EDS elemental maps of (B). (Q-X) SEM-based EDS elemental maps of (D). Boxes in (E-H) mark area magnified in (I-P).

Fig. 4. Representative normalized sulfur K-edge XANES spectra of SLM fascicle and carbonaceous material in matrix around Megasphaera (black lines), as well as model sulfur 
compounds (blue lines). Red lines show best 2-compound fit (dibenzothiophene + gypsum and dibenzothiophene + polyphenylene sulfide in comparison with the matrix carbonaceous material and SLM fascicle spectra, respectively; see Table 1), as determined by LCF using spectra of various model sulfur compounds.

Fig. 5. FIB-EM analysis. (A-O) Preparation and analysis of SLM fascicle transverse section ultra-thin foil. (A) Composite transmitted-light image (assembled from two transmitted-light images separated by line) of phosphatized fossil with SLM fascicle. (B) Composite transmittedlight image (assembled from seven higher magnification images, indicated by boxes), showing SLM fascicle prior to FIB-EM transverse sectioning. (C) Transmitted-light image of the right part of the SLM fascicle in (B) taken at different focal length, showing multiple SLMs in fascicle. (D) SEM (SSD) image and (E) SEM (ETD) images of (A). (F) SEM (SSD) image of SLM fascicle. Arrows in (A, D-F) and dashed line (F) indicate location of FIB transverse section. (G) Magnified SEM (ETD) image of box in (E), showing location targeted for FIB preparation with ion-sputtered rectangle (indicated by arrow in $\mathrm{G})$. (H-N) Sequential SEM (ETD) images acquired during preparation of ultra-thin foil. (H) Location indicated by arrow in (G) magnified and rotated. (I) $1 \mu \mathrm{m}$ thick platinum layer deposited to protect SLM fascicle during ion milling. (J) Initial stages of ion milling. (K) Revelation of SLM fascicle (dark color, indicated by arrow). (L) Toward end of milling process. (M) Rectangular transverse sections of SLMs in fascicle. (N) Ultra-thin foil, after it was removed from thin section and secured to TEM copper grid. (O) SEM (S/TEM) image of 100 nm thick ultra-thin foil following ion-polishing to electron transparency (also shown in Fig. 6A). (P) SEM (ETD) image of SLM transverse section 
(location indicated by arrow in Fig. 2D). pC, porous carbonaceous material; upC, unassociated porous carbonaceous material in cell lumen.

Fig. 6. BF-TEM, BF-S/TEM, and SAED analyses of SLM fascicle transverse section ultra-thin foil. (A) BF-S/TEM image of SLM fascicle transverse section (location indicated by arrow in Fig. 5F) ultra-thin foil, also illustrated in Fig. 5O. Arrow in (A) indicates aluminosilicate. (B-I) TEM-based EDS elemental maps of labelled box in (A). (J-K) BF-TEM (J) and BF-S/TEM (K) images of labelled boxes in (A), showing different mineralization types. (L-Q) SAED patterns of carbonaceous material and apatite from labelled circles in (A, J, K). ncA, nanocrystalline apatite; icA, isopachous apatite; mA, micrometer-sized apatite crystal; pC, porous carbonaceous material; cC, nonporous compressed carbonaceous material.

Fig. 7. SEM images of phosphatic filaments within Megasphaera fossils extracted from unit 4B. (A) Filaments between internal body and outer envelope. (B) Sparsely-branching filaments. (C) Anastomosing (white arrow) and sparsely-branching filaments. (D) Filaments heavily coated with botryoidal cements. (E) Transverse section through filament without axially-located structure (black arrow in C), showing radially-oriented crystals. (F) Transverse section through filament (arrow in D), showing oblong (possibly rectangular) axially-located structure replicated by randomly-oriented nanocrystals. (G) Longitudinal section through filament (arrow in B) showing axially-located structure. (H) Magnified view of axially-located structure (box in G), showing randomly-oriented nanocrystals in axially-located structure surrounded by radiallyoriented prismatic microcrystals. 


\section{A Figure 1}

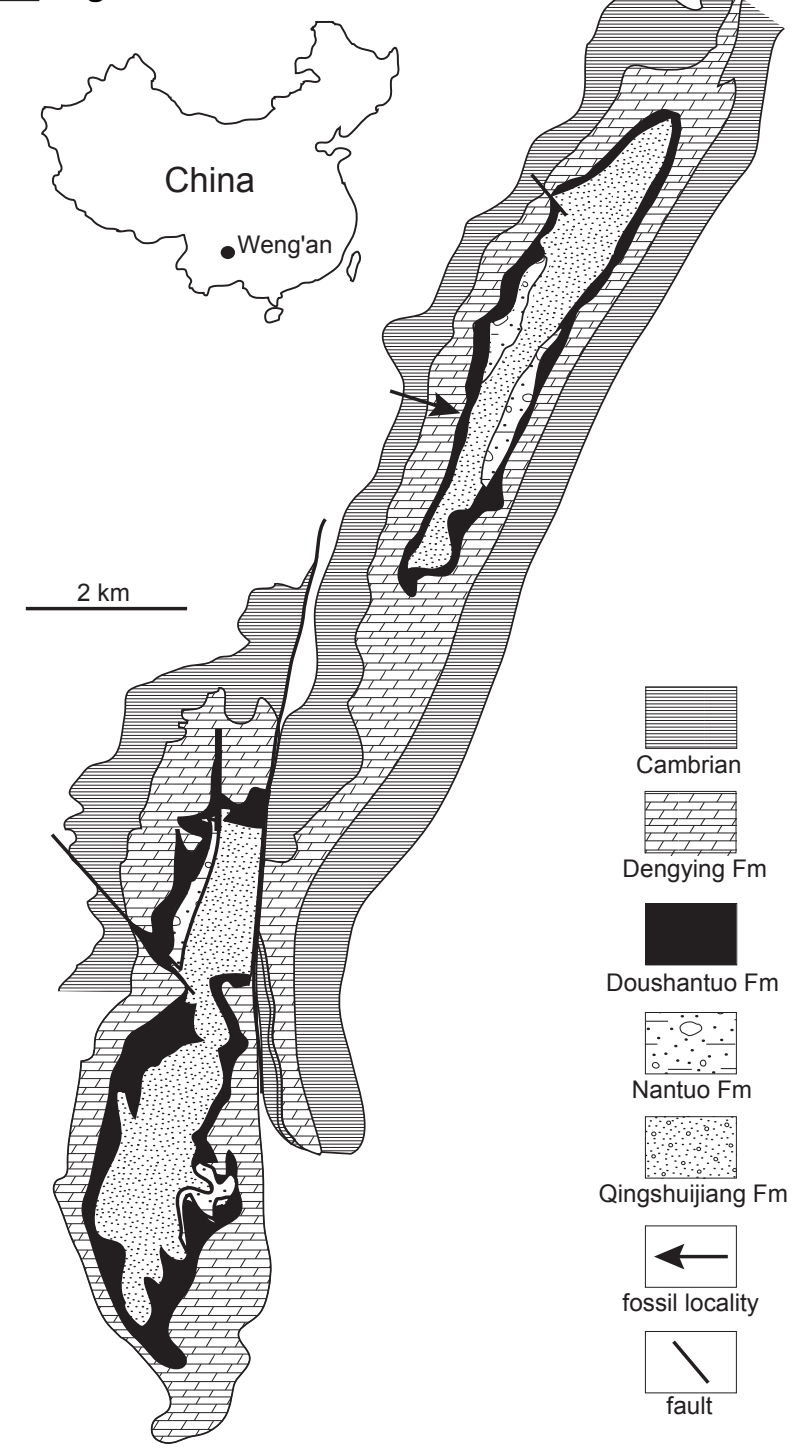

B

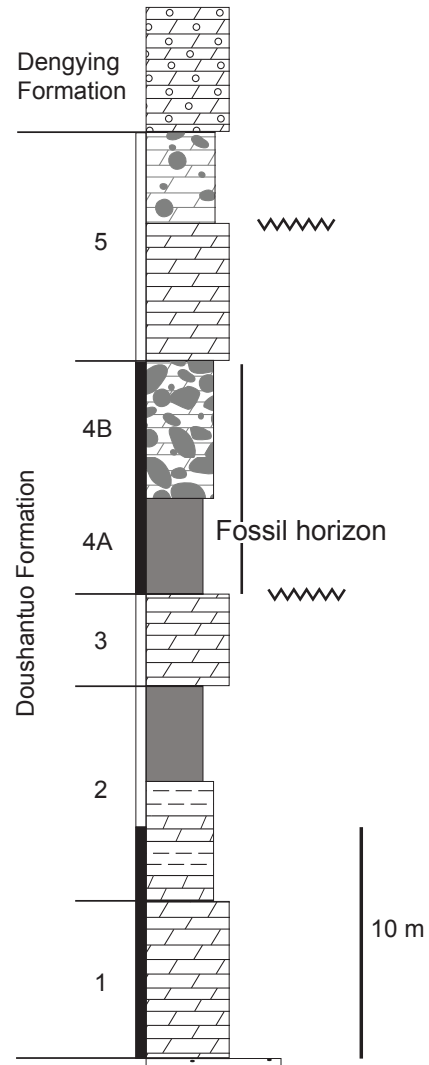

Nantuo

Formation

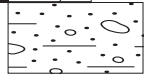

$\because 0 \dot{0}$

Glaciogenic diamictite

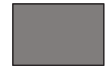

Phosphorite

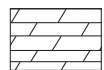

Dolostone

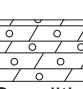

Oncolitic dolostone

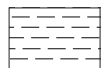

Siltstone/ shale

\section{MWN}

Karstification surface 


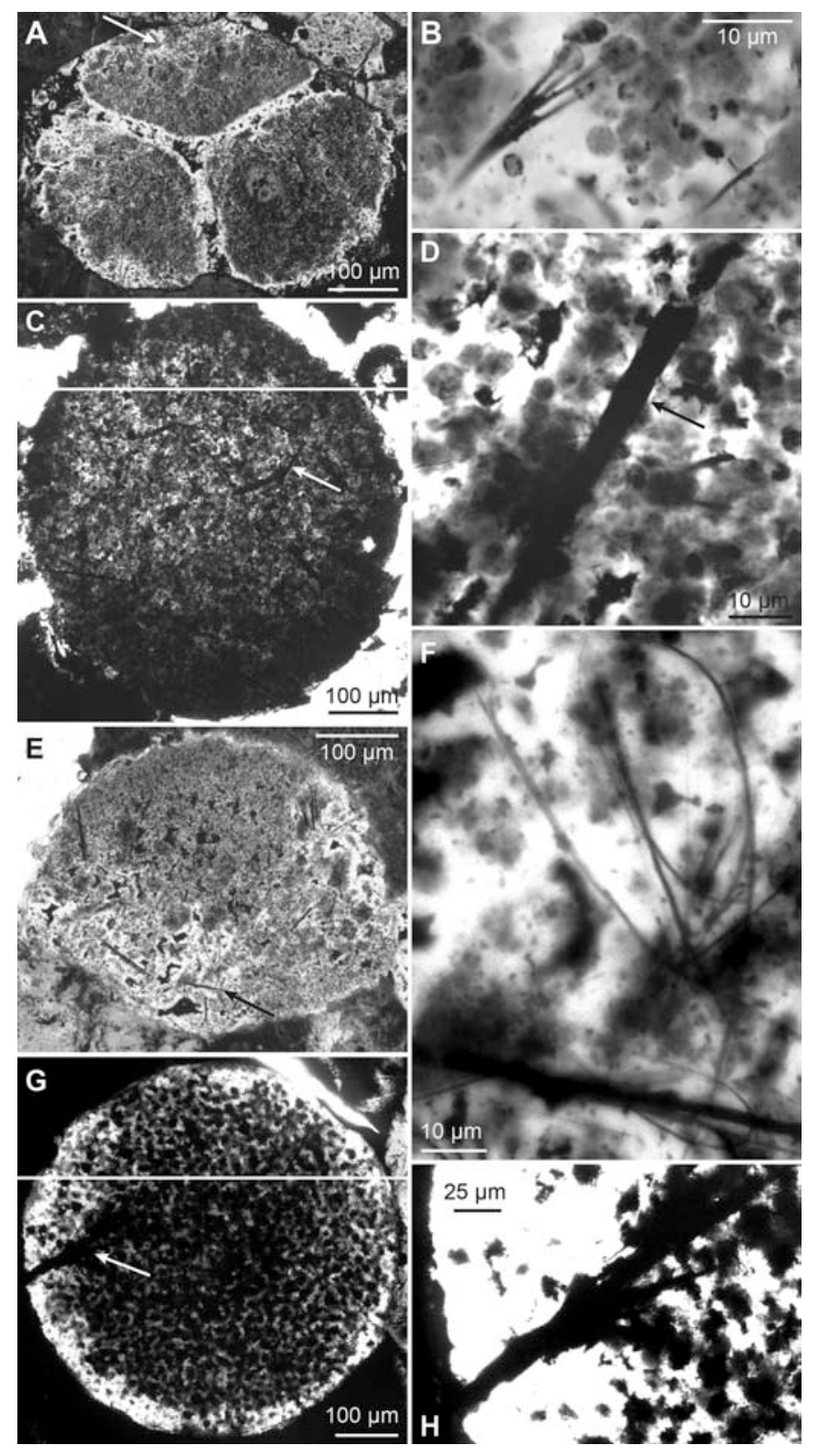

Figure 2 

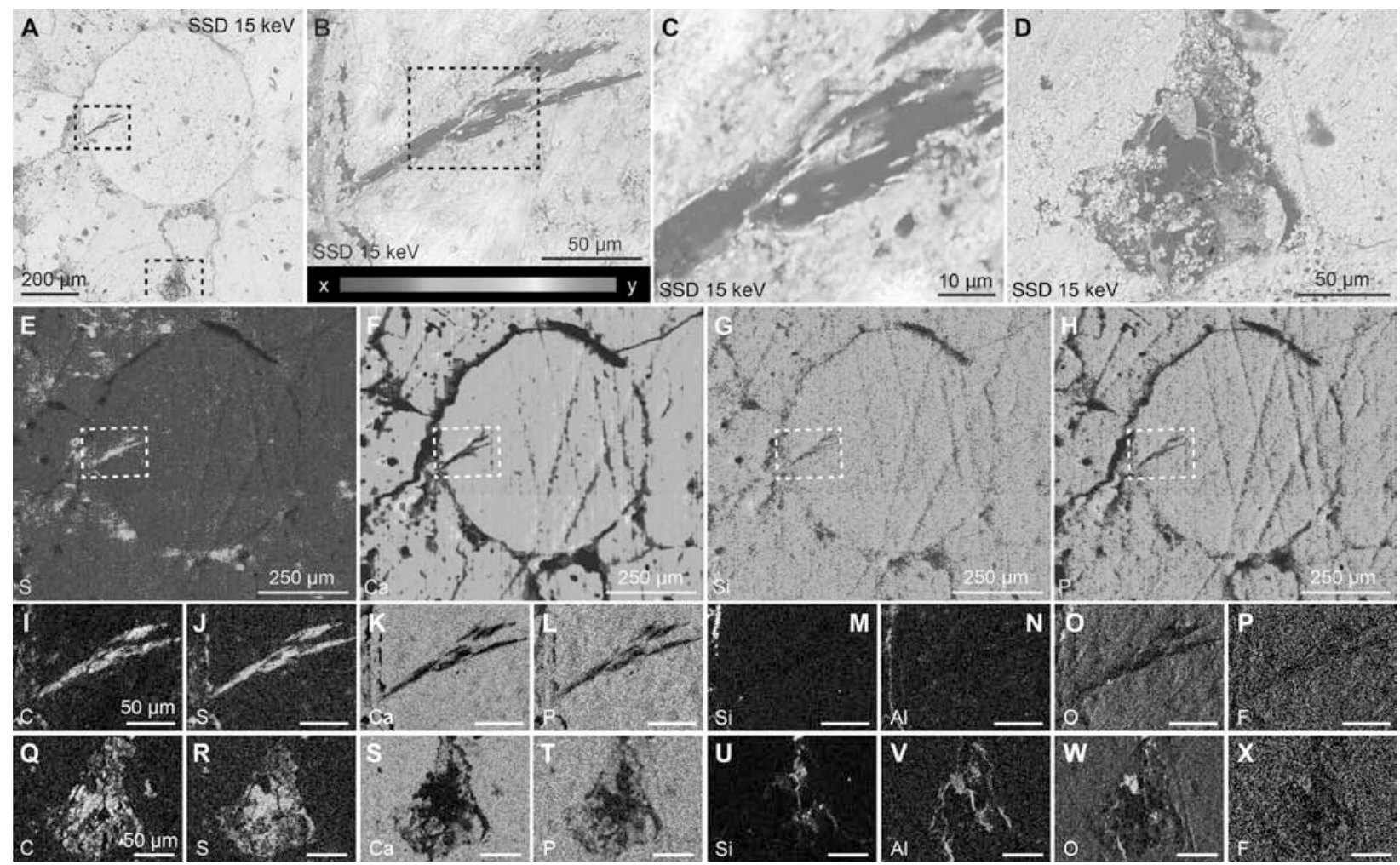

$10 \mu \mathrm{m} S \mathrm{SSD} 15 \mathrm{keV}$
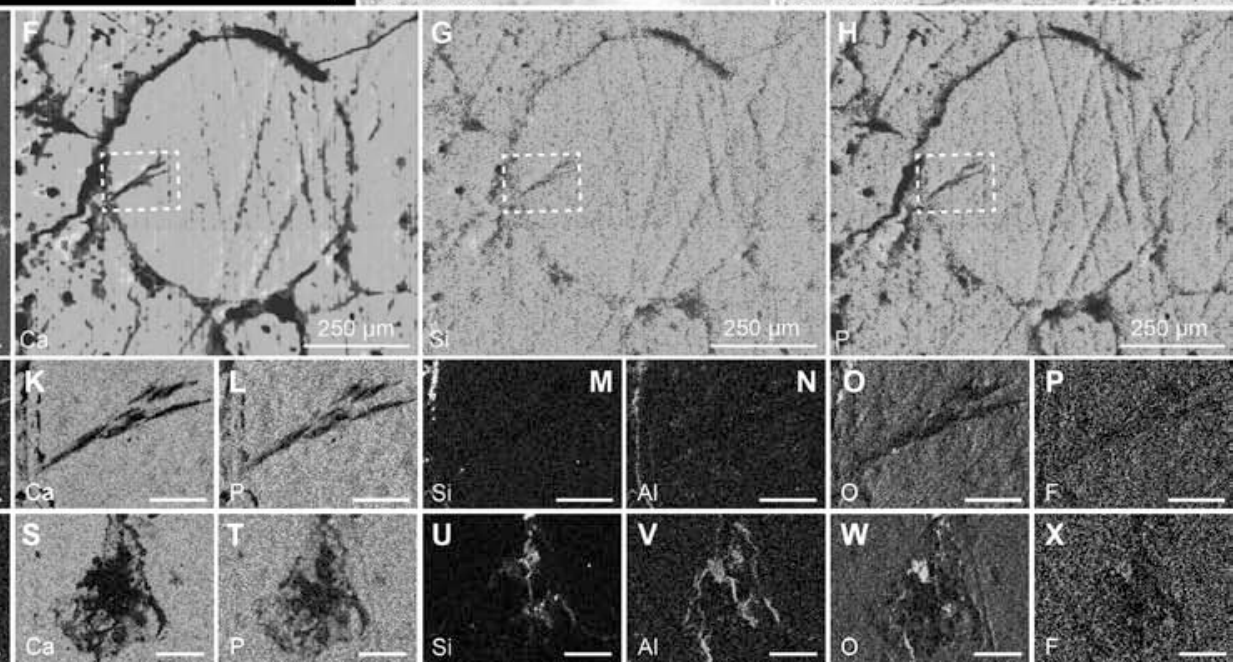

Figure 3 


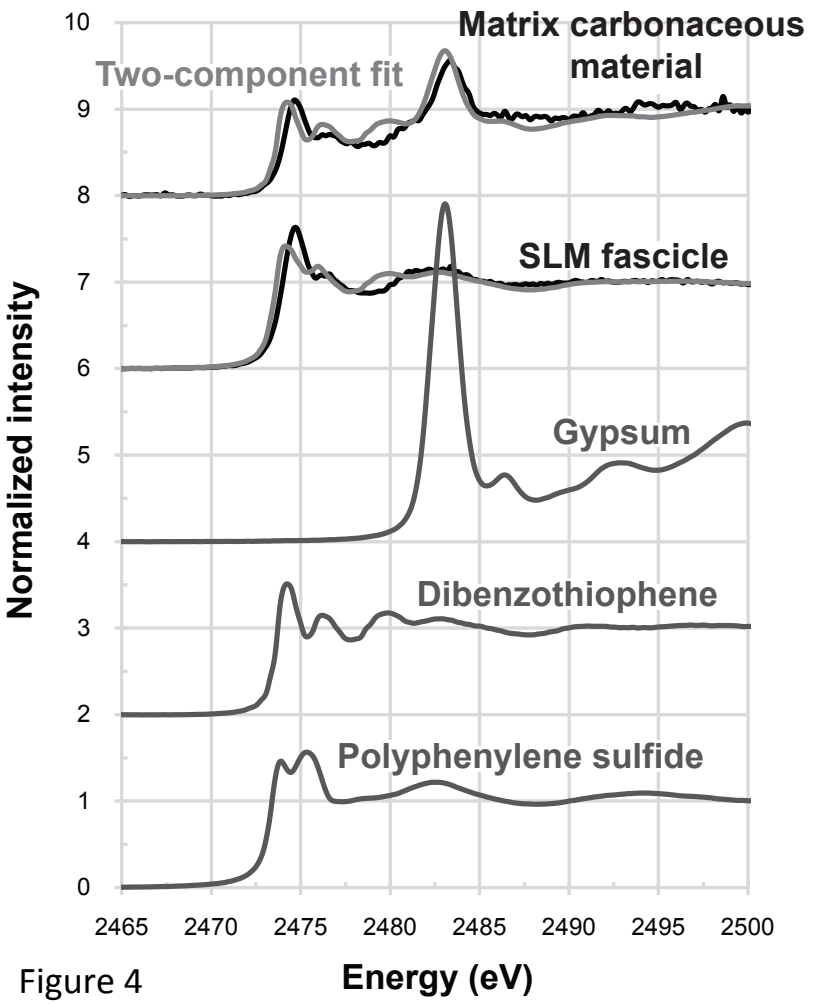




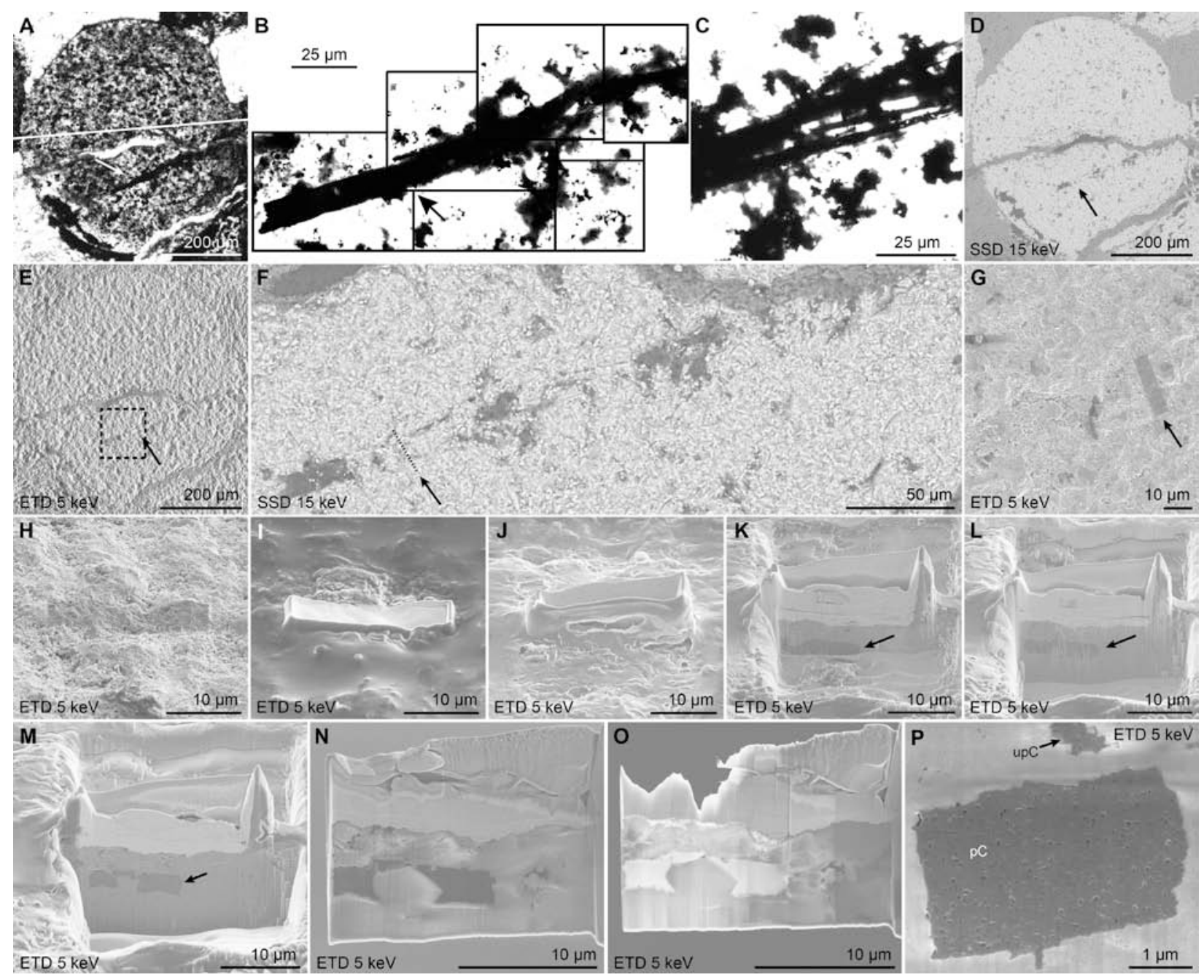

Figure 5 


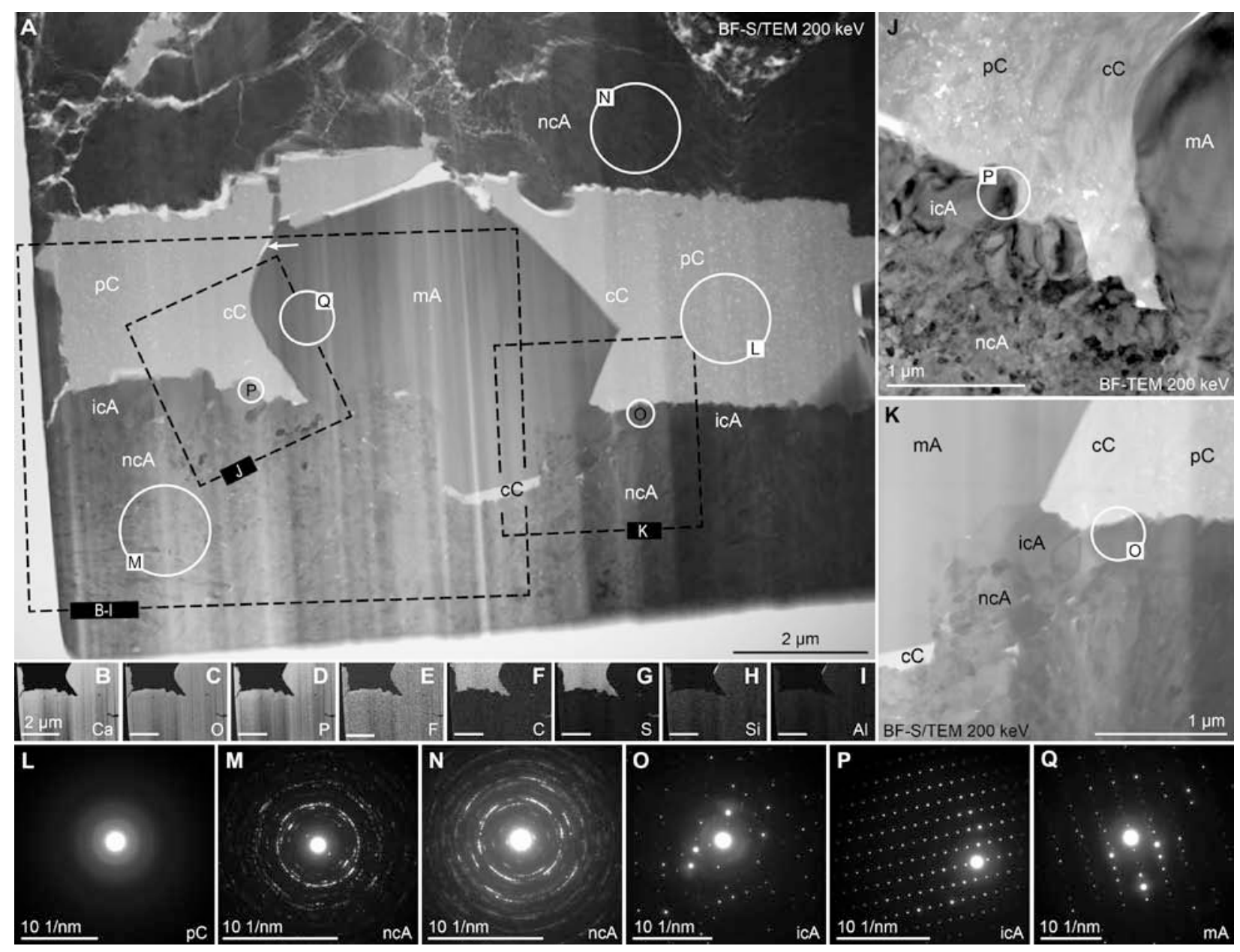

Figure 6 


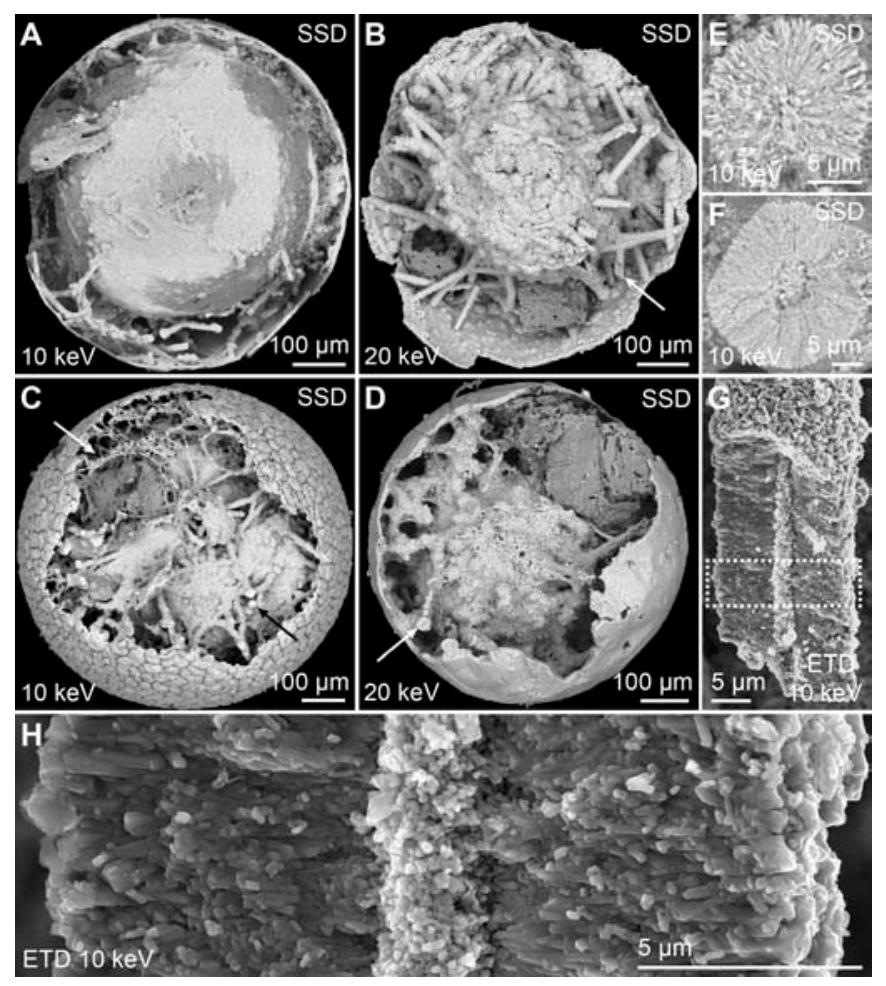

Figure 7 
Table 1. LCF results.

\begin{tabular}{|cccccc} 
Sample location & $\begin{array}{c}\text { Gypsum } \\
\text { (\%) }\end{array}$ & $\begin{array}{c}\text { Dibenzothiophene Polyphenylene } \\
\text { (\%) }\end{array}$ & $\begin{array}{c}\text { Sum } \\
\text { sulfide (\%) }\end{array}$ & $\boldsymbol{R}$ \\
\hline $\begin{array}{c}\text { Matrix carbonaceous } \\
\text { material }\end{array}$ & 23 & 71 & 0 & 94 & 0.018 \\
$\begin{array}{c}\text { SLM fascicle } \\
\text { SLM }\end{array}$ & 0 & 60 & 37 & 98 & 0.010
\end{tabular}

